\title{
Partial efficacy of a VSV-SIV/MVA-SIV vaccine regimen against oral SIV challenge in infant macaques
}

\author{
Marta L. Marthas ${ }^{\mathrm{a}}$, Koen K.A. Van Rompay ${ }^{\mathrm{a}}$, Zachary Abbott $^{\mathrm{a}}$, Patricia Earl ${ }^{\mathrm{b}}$, Linda \\ Buonocore-Buzzellic, Bernard Moss ${ }^{\mathrm{b}}$, Nina F. Rose ${ }^{\mathrm{C}}$, John K. Rose ${ }^{\mathrm{C}}$, Pamela A. \\ Kozlowskid, and Kristina Abel ${ }^{\mathrm{e}}$ \\ ${ }^{a}$ California National Primate Research Center, University of California, Davis, CA, USA \\ bLaboratory of Viral Diseases, National Institute of Allergy and Infectious Diseases, NIH, \\ Bethesda, MD, USA \\ 'Department of Pathology, Yale University School of Medicine, New Haven, CT, USA \\ dDepartment of Microbiology, Immunology and Parasitology, Louisiana State University Health \\ Sciences Center, New Orleans, LA, USA \\ eDepartment of Microbiology and Immunology, School of Medicine, University of North Carolina, \\ Chapel Hill, NC, USA
}

\begin{abstract}
Despite antiretroviral medications, the rate of pediatric HIV-1 infections through breast-milk transmission has been staggering in developing countries. Therefore, the development of a vaccine to protect vulnerable infant populations should be actively pursued. We previously demonstrated that oral immunization of newborn macaques with vesicular stomatitis virus expressing simian immunodeficiency virus genes (VSV-SIV) followed 2 weeks later by an intramuscular boost with modified vaccinia ankara virus expressing SIV (MVA-SIV) successfully induced SIV-specific T and B cell responses in multiple lymphoid tissues, including the tonsil and intestine [13]. In the current study, we tested the oral VSV-SIV prime/systemic MVA-SIV boost vaccine for efficacy against multiple oral SIVmac251 challenges starting two weeks after the booster vaccination. The vaccine did not prevent SIV infection. However, in vaccinated infants, the level of SIV-specific plasma $\operatorname{IgA}$ (but not $\operatorname{IgG}$ ) at the time of challenge was inversely correlated with peak viremia. In addition, the levels of SIV-specific IgA in saliva and plasma were inversely correlated with viral load at euthanasia. Animals with tonsils that contained higher frequencies of SIV-specific TNF- $\alpha$ or IFN- $\gamma$-producing CD8+ T cells and central memory $\mathrm{T}$ cells at euthanasia also had lower viremia. Interestingly, a marked depletion of CD25+ FoxP3+ CD4+ T cells was observed in the tonsils as well as the intestine of these animals, implying that $\mathrm{T}$ regulatory cells may be a major target of SIV infection in infant macaques. Overall, the data suggest that, in infant macaques orally infected with SIV, the co-induction of local antiviral cytotoxic T cells and T regulatory cells that promote the development of IgA responses may result in better control of viral replication. Thus,
\end{abstract}

() 2011 Elsevier Ltd. All rights reserved.

Corresponding Author: Kristina Abel, Ph.D., Assistant Professor, Department of Microbiology and Immunology, School of Medicine, Genetic Medicine Bldg., Rm. 2047, 120 Mason Farm Rd., CB \#7042, Chapel Hill, NC 27599-7042, Phone: (919) 843-9560, Fax: (919)966-6870, abelk@med.unc.edu.

Publisher's Disclaimer: This is a PDF file of an unedited manuscript that has been accepted for publication. As a service to our customers we are providing this early version of the manuscript. The manuscript will undergo copyediting, typesetting, and review of the resulting proof before it is published in its final citable form. Please note that during the production process errors may be discovered which could affect the content, and all legal disclaimers that apply to the journal pertain. 
future vaccination efforts should be directed towards induction of $\operatorname{IgA}$ and mucosal $\mathrm{T}$ cell responses to prevent or reduce virus replication in infants.

\section{Introduction}

Antiretroviral therapy (ART) provided to the HIV-1-infected mother and/or her newborn child can dramatically reduce the risk of HIV vertical transmission [1-3]. A large clinical trial in Malawi recently demonstrated that vertical transmission of HIV could be further reduced if the period of ART to the newborn was extended for several weeks [4,5]. However, in many resource-poor countries, access to ART is still limited. Thus, pediatric HIV infections continue to occur at a staggering rate. Considering that there is no HIV vaccine available for preventing HIV transmission in adults, and that the majority of newly infected people are women of child-bearing age, the development of a pediatric HIV vaccine should be pursued in parallel with improved antiretroviral intervention strategies and adult HIV vaccine development [6-10].

A large proportion of pediatric HIV infections are due to breast milk transmission. In infant rhesus macaques, the tonsil and intestinal tissues represent the primary sites of viral replication after oral SIV infection [11]. Therefore, we reasoned that a vaccine intended to prevent oral HIV infection of infants should induce immune responses at these sites. A pediatric HIV vaccine should also be administered as early after birth as possible, with accelerated boosting intervals, to protect the newborn against the frequent and continuous exposure to HIV in breast milk.

We previously showed that systemic administration of poxvirus-based SIV vaccine candidates to newborn macaques provided partial protection against oral SIV challenge and prolonged the survival of infants that became infected [12]. Recently, we demonstrated that an oral prime with replication-attenuated Vesicular Stomatitis Virus vector containing multiple SIV genes (VSV-SIV), followed by a systemic boost with Modified Vaccinia Ankara virus containing SIV genes (MVA-SIV) induced SIV-specific T and B cell responses in blood and tissues of infant macaques [13]. Although SIV-specific T cell responses were relatively low, they were detectable in multiple lymphoid and mucosal tissues. Systemic antibody responses to SIV were consistently induced in all vaccinated animals by 4 weeks. Therefore, in the current study, we used a new cohort of infant macaques to test whether the neonatal VSV-SIV/MVA-SIV vaccine regimen was effective for preventing oral SIV infection. While vaccine-induced immune responses did not prevent infection and viral dissemination, the vaccinated animals with SIV-specific IgA at the time of oral challenge, and with mucosal and systemic SIV-specific antibody and T cell responses after challenge had lower levels of virus replication than animals in which $\mathrm{T}$ and $\mathrm{B}$ cell responses were low and detected in fewer tissues.

\section{Materials and Methods}

\section{Animals}

Newborn rhesus macaques (Macacca mulatta), born to animals from the HIV-2, SIV, type D retrovirus, and simian T-cell lymphotropic virus type 1 free colony, were hand-reared in the nursery of the California National Primate Research Center (CNPRC) as previously described [14]. The animals were housed in accordance with the standards set forth by the American Association for Accreditation of Laboratory Animal Care, and all procedures were approved by the Animal Use and Care Committee at UC Davis. For blood collections and immunizations, animals were immobilized with $10 \mathrm{mg} / \mathrm{kg}$ of ketamine-HCL (ParkeDavis, Morris Plains, NC) given by the intramuscular (i.m.) route. A total of 16 infant 
macaques were included in the vaccination study. Group 1 animals were immunized with VSV-SIV/MVA-SIV. Age-matched placebo control animals (Group 2) received mock immunizations (see below). Both male and female infant macaques were assigned to groups randomly. The MHC haplotype at the time of birth was unknown and thus, could not be considered in the group assignment. Subsequent MHC typing revealed that 2 animals in the vaccine group and 3 animals in the control group were positive for the MamuA*01 allele (Table 1). Animals were not typed for MamuB*08 or B*17.

\section{Immunizations}

Animals in Group 1 were immunized within 6 days of birth with VSV-SIV. The vaccine was administered orally in a volume of $1 \mathrm{ml}$ containing $10^{7}$ plaque-forming units (PFU) of each recombinant VSV construct: VSV-SIVmac239gag, -SIV mac239pol, -SIVmac239envG-1 (SIV env inserted in lieu of the VSV G gene). Two weeks later, animals were given an i.m. booster vaccination with $1 \mathrm{ml}$ recombinant MVA-SIV vaccine consisting of $10^{8}$ infectious units (IU) of MVA-SIVmac239gag-pol (termed vJH4) plus $10^{8}$ IU of MVA-SIVmac239env $[12,15]$. The MVA-SIV was injected in $250 \mu \mathrm{l}$ volumes at 4 sites. The naive control animals in Group 2 were orally or i.m. immunized with $1 \mathrm{ml}$ RPMI1640 at the same time points. Empty vectors were not used for mock immunizations as in our previous study [13] because it was not possible to justify the inclusion of more valuable nonhuman primates as infection controls before confirming that the potential vaccine had any efficacy.

\section{SIVmac251 oral challenge}

Two weeks after the $2^{\text {nd }}$ immunization, all animals were repeatedly challenged by the oral route with SIVmac251 as previously described $[11,12]$. Briefly, animals were bottle-fed 3

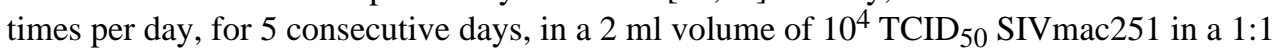
mixture with RPMI1640 in sucrose. The uncloned SIVmac251 (stock 6/04) was propagated in rhesus PBMC and had been titrated in vitro and in vivo to confirm infectivity. This virus stock was similar to the SIVmac251 stocks that were used for oral SIV challenge in our prior studies as it was derived from the same seed stock (Table 2).

\section{Sample collection and processing}

EDTA anticoagulated blood samples were collected weekly or biweekly based on allowable blood volumes. Plasma was harvested after centrifugation of the blood and stored immediately at $-80^{\circ} \mathrm{C}$ for antibody and virological assessment. The cellular blood fraction was resuspended in Dulbecco's phosphate-buffered saline (DPBS) lacking $\mathrm{Ca}^{2+}$ and $\mathrm{Mg}^{2+}$. Peripheral blood mononuclear cells (PBMC) were isolated by density gradient centrifugation using Lymphocyte Separation Medium (MP Biomedicals, Solon, OH). PBMC were washed twice with DPBS followed by complete RPMI (RPMI 1640 supplemented with $10 \%$ FBS, penicillin, streptomycin and L-glutamine).

To measure immune responses in various tissues, animals were euthanized approximately 8-10 weeks after they became infected. At the time of euthanasia, the following tissues were collected: tonsils, submandibular lymph nodes (LN), retropharyngeal LN, axillary and mesenteric LN, and intestinal tissues (ileum, colon). Tissue cell suspensions were prepared as previously described [13]. Briefly, LN were carefully dissected with scalpels, passed through a cell strainer $(40 \mu \mathrm{m})$, and washed twice with complete RPMI 1640. Intestinal tissues were thoroughly rinsed with DPBS, cut into small pieces with scalpels, and subjected to a total of 3 digestions for 30 minutes at $37^{\circ} \mathrm{C}$ in $30 \mathrm{ml}$ of RPMI 1640 supplemented with $7.5 \%$ FBS, antibiotics, amphotericin B, and $0.5 \mathrm{mg} / \mathrm{ml}$ collagenase type II (Sigma, St. Louis, $\mathrm{MO})$. After each digestion, the supernatant containing released cells was transferred into a fresh centrifuge tube and washed twice with PBS. After three digestion steps, the cells were 
combined and centrifuged on a gradient of 65\% and 35\% Percoll (Sigma). Lymphocytes were collected from the interphase and washed twice.

Saliva was collected at euthanasia for mucosal antibody assessment. Saliva was collected using sterile, cellulose acetate absorbent Weck-Cel sponges [16]. Two sponges were used to sample salivary fluid from each infant by placing them between the cheek and gum on the side of the mouth where saliva is pooling. The sponges were allowed to absorb fluid for a minimum of 5 minutes. After this time, the sponges were placed inside a $5 \mathrm{ml}$ tissue culture tube, placed on ice, then stored at $-80^{\circ} \mathrm{C}$. Secretions were extracted as previously described [16]. Briefly, sponges were thawed and eluted by ultracentrifugation with buffer in the upper chamber of a Corning SpinX $0.45 \mu \mathrm{m}$ microspin filter assembly. The secretion was aliquoted and stored at $-80^{\circ} \mathrm{C}$ for analysis of SIV-specific antibodies and total immunoglobulin (Ig) by ELISA. Note that saliva was not collected at the time of challenge to avoid causing micro-abrasions that could facilitate viral entry in the oral cavity. In addition, we have found that infant macaques rarely have sufficient total IgA in saliva at this time (4 wks after birth) to detect specific antibody (Kozlowski, unpublished data). Sampling other mucosal sites (e.g. rectal mucosa, lung) would not have provided data relevant to oral SIV infection and thus did not justify the exposure of infant macaques to invasive procedures that could jeopardize the animals' health and the study outcome.

\section{SIV-specific antibodies and total IgA}

The concentrations of anti-SIV envelope (Env) or anti-SIV Gag,Pol antibodies in plasma or saliva were quantitated by ELISA as described [17] using micotiter plates coated respectively with 100ng/well of SIVmac251 rgp130 (ImmunoDiagnostics, Woburn, MA) or $100 \mu \mathrm{l} /$ well of 1/400 SIVmac239 whole viral lysate (Advanced Biotechnologies Inc., Columbia, MD), which does not contain detectable Env protein at this dilution. For total IgA ELISA [16], plates were coated with goat anti-monkey IgA (AlphaDiagnostic, San Antonio, TX). Previously calibrated preparations of macaque sera containing known amounts of antibody or IgA were used to generate standard curves in these assays [17]. The plates were developed with biotinylated affinity-purified goat anti-monkey IgA antibody (AlphaDiagnostic) or -human IgG (SouthernBiotech, Birmingham, AL), avidin-peroxidase (Sigma), and TMB (KPL, Gaithersburg, MD). The plates were read in a SpectraMax M5 plate reader (Molecular Devices, Sunnyvale, CA) and concentrations of antibody in specimens were interpolated from 4-parameter standard curves constructed with the SoftMax Pro computer program (Molecular Devices). The specific activity for IgA in saliva or plasma was calculated by dividing the concentration of SIV-specific IgA antibody in the sample by the total IgA concentration. A sample was considered to have significant specific activity if it was $\geq$ mean $+3 \mathrm{SD}$ for negative controls and 3.4-fold greater than the animal's preimmune value. The specific serum $\operatorname{IgG}$ antibody concentration was considered significant if it was 3.4-fold greater than the preimmune concentration.

\section{Flow cytometric assessment of immune activation and SIV-specific T cell immune responses}

Phenotypic characterization of T cell populations was combined with the analysis of SIVspecific immune responses. To assess $\mathrm{T}$ cell activation, $1 \times 10^{6}$ cells were stained with CD3 (clone SP34.2)-PacificBlue, CD4 (clone L200)-PE-Cy7, CD8 (clone TPA8)-Alexa 700, Ki67 (clone B56)-FITC, and CCR5 (clone 3A9)-PE. T cell differentiation was evaluated by using CD45RA (clone L48) and CCR7 (clone 3D12) antibodies to distinguish naïve $\left(\mathrm{CD} 45 \mathrm{RA}^{+} \mathrm{CCR}^{+}\right)$, central memory $\left(\mathrm{CD} 45 \mathrm{RA}^{-} \mathrm{CCR} 7^{+}\right)$and effector/effector memory $\left(\mathrm{CD}_{5} 5 \mathrm{RA}^{+/-} \mathrm{CCR}^{-}\right) \mathrm{T}$ cells. Regulatory $\mathrm{T}$ cells (Treg) were characterized as $\mathrm{CD}^{+} \mathrm{CD}^{+}$ $\mathrm{CD} 25^{+} \mathrm{FoxP}^{+}$cells. The CD25 and FoxP3 antibodies were from Miltenyi (clone A251; 
Miltenyi Biotech Inc., Auburn, CA) and BioLegend (clone 206D; BioLegend, San Diego, CA), respectively, all other antibodies were from Beckton-Dickinson (San Jose, CA).

To measure SIV-specific T cell responses by intracellular cytokine staining, PBMC and tissue cell suspensions $\left(1 \times 10^{6}\right.$ cells) were stimulated in vitro in the presence of $0.5 \mu \mathrm{g} / \mathrm{ml}$ of anti-CD49d and anti-CD28 antibodies with either $300 \mathrm{ng} / \mathrm{ml}$ aldrithiol 2-inactivated SIVmac239 (kindly provided by Dr. Jeff Lifson, NCI) or with $5 \mu \mathrm{g} / \mathrm{ml}$ of pooled, overlapping SIV Gag p27 peptides (NIH AIDS Research and Reference Reagent Program). Control cultures were stimulated with medium only (negative control) or with $50 \mathrm{ng} / \mathrm{ml}$ PMA plus 250ng/ml ionomycin (positive controls; Sigma). Cells were cultured for 6 hours at $37^{\circ} \mathrm{C}$ and $5 \% \mathrm{CO}_{2}$ with $10 \mu \mathrm{g} / \mathrm{ml}$ Brefeldin A (Sigma) being added 1 hour after culture initiation. Note that Beckton-Dickinson protocols were followed for all staining panels except the regulatory $\mathrm{T}$ cell panel, which was done according to Biolegend protocols. CD4 ${ }^{+}$ and $\mathrm{CD} 8^{+} \mathrm{T}$ cells were evaluated for the production of IFN- $\gamma$ and TNF- $\alpha$ in response to SIV antigen stimulation. Samples were acquired on a FACS ARIA instrument (BecktonDickinson). A total of 30,000 events were acquired for $\mathrm{T}$ cell activation and regulatory $\mathrm{T}$ cells, and 300,000 events were acquired to assess SIV-specific T cell responses. Data were analyzed using FlowJo software (TreeStar, Ashland, OR). Boolean gating was used for determining frequencies of multifunctional cells. Frequencies of cytokine-positive cells are reported as the percentage within $\mathrm{CD}^{+}{ }^{+}$or $\mathrm{CD}^{+} \mathrm{T}$ cell populations. Antigen-stimulated cells were considered positive if the percentage of cytokine-positive cells was 2 -fold greater than the percentage in the unstimulated medium control and if the percentage was $\geq 0.04 \%$ after subtraction of the medium control value.

\section{Virological analysis}

Plasma samples were analyzed for SIV RNA by a real time reverse transcriptase polymerase chain reaction (RT-PCR) assay as described [18]. Data are reported as viral RNA copies per $\mathrm{ml}$ of plasma.

\section{Statistical analysis}

Individual parameters in a single tissue at specific time points were compared between control and vaccinated macaques using the Mann-Whitney test. One-way ANOVA with subsequent Tukey comparisons was applied to define statistical differences for an individual parameter across multiple tissues. To compare virus replication levels over time between vaccinated and unvaccinated macaques, area-under-the-curve (AUC) was calculated for $\log _{10}$ SIV plasma RNA levels from day 0 through week 8 after infection. Area-under-thecurve values were also calculated for logarithmically transformed plasma IgG and IgA antibody concentrations from week 0 - 8 after SIV challenge and compared between groups using the Mann-Whitney test. Weight gain of animals in the two groups was compared using linear regression analysis. All statistical analyses, including the testing for correlations between two parameters, were performed using GraphPad Prism and InSTAT Software (GraphPad, Inc., La Jolla, CA). P values less than or equal to 0.05 were considered significant.

\section{Results}

\section{Limited effect of VSV-SIV/MVA-SIV vaccination on viremia in infant macaques orally challenged with SIV}

Repeated oral exposure of naive infant macaques to SIVmac251 resulted in systemic infection in 6/8 animals within two weeks of the first SIV exposure (Figure 1A). The 2 virus-negative animals (\#37919 and \#38125) were exposed to a second round of 15 oral SIV exposures at 7 weeks of age ( 3 weeks after the first challenge round). Both animals became 
infected within two weeks (Figure 1A; gray lines). Peak viremia and viral set point ranged from $10^{6}-10^{8}$ copies of viral RNA per ml of plasma in all animals, including the rechallenged animals, which had peak viremia of 6.7 and $7.8 \log 10$ viral RNA copies $/ \mathrm{ml}$ after the second round of challenge (Figure 1A and Table 1). Vaccination of infant macaques with VSV-SIV/MVA-SIV did not prevent infection after oral SIV exposure. As in the control macaques, $6 / 8$ vaccinated animals became systemically infected after 15 oral SIV exposures, and the remaining 2 vaccinees (\#38129 and \#38130) were infected after a second round of challenges (Figure 1B). Based on our experience with this oral SIV challenge model in infant macaques, we are confident that the 2 naive and 2 vaccinated animals which received two rounds of oral SIV exposures were infected after the second round, as opposed to exhibiting delayed infection after the first round. Thus, in all Figures and data discussions, the post-challenge results for these animals (designated by gray color) correspond to weeks after the second round of challenge. This facilitated comparison of results for all animals in the study.

One of the 8 vaccinated macaques (\#38129) reached a viral set point below $10^{6}$ viral RNA copies per $\mathrm{ml}$, and 3 other vaccinated animals reached a set point near $10^{6}$ copies per $\mathrm{ml}$, the lower limit of viremia in the naive macaques (Figure 1). There were were no statistically significant differences in peak viremia or viral set point between the vaccinated and unvaccinated macaques. There was a trend, however, towards lower average plasma viral loads in vaccinated compared to unvaccinated animals between weeks 4 to 8 , and this difference reached statistical significance at the week 8 post-challenge time point $(\mathrm{P}=0.0321)$ (Figure 1C). Area-under-the curve- analysis (AUC) of plasma viremia until week 8 similarly showed a trend towards slightly better control of virus replication in vaccinated compared to unvaccinated macaques (Table 1). As animal numbers declined after week 8, later time points were excluded from the analysis. The MHC genotype did not appear to play a role in vaccine-mediated control of virus replication. The 2 naive control animals with the lowest levels of virus were MamuA*01-positive. However, in the vaccine group, the animal (\#37898) with the highest viral load was also MamuA*01-positive.

Consistent with the plasma viral RNA levels, vaccinated animals showed a higher average weight gain compared to the naive animals (Figure $1 \mathrm{D}, \mathrm{P}<0.01$ by linear regression analysis). Weight gain is considered a critical clinical parameter in pediatric studies as failure to thrive is generally associated with a poorer prognosis.

\section{SIV-specific $T$ cell responses}

a) Vaccine-induced $\mathrm{T}$ cell responses in blood prior to challenge-We recently showed that oral VSV-SIV prime/systemic MVA-SIV boost in infant macaques induces SIV-specific $\mathrm{CD} 4^{+}$and $\mathrm{CD} 8^{+} \mathrm{T}$ cells in lymph nodes draining the oral cavity in addition to systemic lymphoid tissues and blood [13]. In the current study, the presence of SIV-specific $\mathrm{T}$ cells in tissues could not be assessed before challenge because it is not feasible to obtain biopsies from infant macaques at this early age without compromising survival. SIV-specific $\mathrm{T}$ cell responses were detected in blood of 3 of 8 vaccinated infants at the time of oral SIV challenge (Table 1). However, the frequencies of SIV-specific T cells in blood at the time of challenge did not correlate with viral replication after infection.

b) T cell responses in blood after oral SIV challenge-After challenge, 6 of 8 vaccinated macaques demonstrated SIV-specific T cell responses (Figure 2A). These postchallenge SIV-specific T cell responses in blood could not be predicted based on prechallenge SIV-specific T cell responses in blood (Table 1). Over time, SIV-specific T cells in blood waned and were evident in only 2 of 8 vaccinated animals at euthanasia (Table 1). 
SIV-specific $\mathrm{T}$ cell responses in blood of naive infant macaques were similar to those in the vaccinees. SIV-specific T cell responses were observed in 6 of 8 controls after challenge, but at the time of euthanasia they were detected in only 1 control animal (Table 1, Figure 2B). The similar antigen-specific $\mathrm{CD} 8^{+} \mathrm{T}$ cell responses in vaccinated and naive macaques (Figures $2 \mathrm{~A}$ and $\mathrm{B}$ ) is consistent with the finding that $\mathrm{CD} 8^{+} \mathrm{T}$ cells in both groups were comparably activated after SIV challenge (Figures $2 \mathrm{C}$ and $\mathrm{D}$ ). In all vaccinated and control animals, the frequencies of $\mathrm{CCR}^{+}$and $\mathrm{Ki} 67^{+} \mathrm{CD} 8^{+} \mathrm{T}$ cells in blood rapidly increased 1-2 weeks after oral SIV infection and then returned to baseline levels (Figures 2C and 2D).

\section{c) SIV-specific $\mathrm{T}$ cell responses in lymphoid tissues at the time of euthanasia}

-Overall, 7 of 8 vaccinated infants had SIV-specific $\mathrm{CD} 4^{+}$and/or $\mathrm{CD} 8^{+} \mathrm{T}$ cell responses in at least one tissue examined at euthanasia. Due to insufficient cell numbers, the presence of specific T cells in tonsils could only be analyzed in 5 of the vaccinated animals (\#38129, \#37907, \#38141, \#37902, \#37908). In regard to the tissues most proximal to probable sites of viral entry, 5 of 8 vaccinated macaques had SIV-specific T cell responses in lymph nodes draining the oral cavity (tonsil, submandibular LN) and 4 of these macaques also had SIVspecific $\mathrm{T}$ cells in the ileum (Table 1 ). In contrast, only 3 of 8 naive animals demonstrated $\mathrm{SIV}$-specific $\mathrm{CD}^{+} \mathrm{T}$ cells in tissues, and these were observed in fewer tissues (Table 1). However, 2 additional control animals mounted $\mathrm{CD}^{+}{ }^{+} \mathrm{T}$ cell responses to SIV. Thus, SIVspecific $\mathrm{T}$ cell responses were detected in submandibular lymph nodes of 4 of 8 and in the ileum of 2 of 8 naive controls. None of the 4 tonsil specimens from unvaccinated macaques (\#38115, \#37919, \#38128, \#37921) had SIV-specific T cells (Table 1), including the 2 animals with the lowest virus loads in blood (MamuA*01-positives \#37919 and \#38115). Overall, in both vaccinated and unvaccinated animals, SIV-specific T cells were induced in relatively low frequencies (Table 1), and the majority of SIV-specific T cells produced only a single cytokine, with TNF- $\alpha$ responses dominating over IFN- $\gamma$ responses (data not shown).

The 3 vaccinated macaques (\#38129, 37907, and 38141) with SIV Gag p27-specific T cell responses in the tonsil had the lowest viral loads at the time of euthanasia (Figure 1, Table 1). Also, there were higher frequencies of central memory $\left(\mathrm{T}_{\mathrm{CM}}\right)$, and lower frequencies of effector/effector memory ( $\mathrm{T}_{\mathrm{Eff}}$ ) $\mathrm{CD} 4^{+}$and $\mathrm{CD} 8^{+} \mathrm{T}$ cells in the tonsil of vaccinated (but not unvaccinated) macaques, and both of these were associated with lower levels of virus replication (Figure 3 ). $\mathrm{T}_{\mathrm{CM}}$ are functionally characterized by more persistent IL-2 production compared to effector T cells [19]. In the current study though, IL-2 production by antigen-specific cells was not measured. Based on phenotypic markers, SIV-specific TNF- $\alpha$ and IFN- $\gamma$ producing cells were found in both $\mathrm{T}_{\mathrm{CM}}\left(\mathrm{CD} 4 \mathrm{RA}^{-} \mathrm{CCR} 7^{+}\right)$and $\mathrm{T}_{\mathrm{Eff}}$ $\mathrm{CD} 8^{+} \mathrm{T}$ cell populations $\left(\mathrm{CD} 45 \mathrm{RA}^{+/-} \mathrm{CCR}^{-}\right.$) (Figure 4 ). Together, these $\mathrm{T}$ cell data for vaccinated macaques are consistent with the potential for local immune responses at the site of virus exposure to control virus replication.

The overall slightly broader tissue detection of SIV-specific T cells in the vaccinated compared to unvaccinated macaques (Table 1) suggests that these responses reflected vaccine-induced memory $\mathrm{T}$ cell responses. Although these tissue responses were only measured at the time of euthanasia, this conclusion is consistent with the detection of VSVSIV/ MVA-SIV-induced SIV-specific T cell responses in multiple tissues at 4 weeks of age in our prior study [13], which was the time of challenge here.

Thus, although vaccine-induced T cells did not prevent infection, there were some noteworthy differences in post-challenge SIV-specific tissue T cell responses between vaccinated and unvaccinated infant macaques that could have contributed to reduced viremia in some vaccinated animals. 


\section{SIV-specific antibody responses}

a) Vaccine-induced antibodies at the time of oral SIV challenge-We have already demonstrated that VSV-SIV/MVA-SIV vaccination of infant macaques induces SIV-specific IgG and IgA responses to SIV Env and Gag,Pol proteins [13]. Consistent with these data, all vaccinated infant macaques in this study had detectable SIV-specific IgG antibodies in plasma at the time of challenge (Figure 5A). In addition, most (6/8) vaccinated animals had detectable, albeit low, levels of SIV Env-specific IgA in plasma (Figure 5B). Importantly, in these 6 animals, SIV-specific plasma IgA antibody levels at the time of challenge, despite being low, were inversely correlated with acute peak plasma viral RNA levels (Figure 6A). This inverse correlation between SIV Env-specific plasma IgA at the time of challenge and viremia was still evident when animals reached viral set-point at week 4 after oral SIV challenge ( $\mathrm{P}=0.02, \mathrm{r}=-0.8822)$. In contrast, $\mathrm{SIV}$-specific plasma IgG antibody levels at the time of challenge did not correlate with peak viremia (Figure 6B).

b) SIV-specific systemic and mucosal antibody responses after SIV challenge

-Within the first 2-4 weeks after challenge, SIV-specific IgG further increased in plasma of all vaccinated animals (Figure 5). SIV Env and Gag,Pol-specific plasma IgG AUC levels from weeks 0 - 8 were significantly higher in vaccinated than unvaccinated macaques $(\mathrm{P}=0.0002$ and $\mathrm{P}=0.003$, respectively; Table 1 ). Moreover, 3 of 8 naive macaques ( $\# 38112$, 38122, and 38125) failed to develop SIV-specific IgG throughout the study and these had the highest plasma viremia (Table 1). The SIV-specific plasma IgA was detected in all vaccinees and reached higher levels compared to control macaques (Figure 5B, $\mathrm{P}=0.01$ for AUC analysis of SIV Env-specific IgA; Table 1). Further, in contrast to vaccinated macaques, only $50 \%$ of the unvaccinated macaques developed SIV-specific IgA antibodies in plasma after oral SIV challenge.

At the time of euthanasia, SIV-specific IgA antibodies were detected in saliva from 5 of 8 vaccinated but only 3 of 8 unvaccinated macaques (Table 1, Figure 6). Some IgA transudation from serum into saliva likely occurred in these animals; however, local IgA production was suggested by the higher specific activity of SIV-specific IgA in saliva compared to plasma (Figures 6C and 6D). Consistent with the inverse correlation between SIV Env-specific IgA at the time of challenge and peak viremia, higher SIV Env and Gag, Pol-specific plasma IgA in vaccinated macaques at the time of euthanasia correlated with better control of virus replication (Figures $6 \mathrm{E}$ and $6 \mathrm{~F}$ ). In the 3 vaccinated animals with the highest viral loads, SIV Env-specific IgA increased only slightly (\#37908, \#37898) or not at all (\#38142) (Figure 5B).

The 3 vaccinated animals with the highest SIV-specific plasma IgG and IgA antibody levels throughout the post-challenge period and with high salivary IgA levels at the time of euthanasia (\#38129, 37907, and 38141) also had SIV Gag p27-specific CD8 ${ }^{+} \mathrm{T}$ cell responses in the tonsil (Table 1). The finding of both SIV-specific tonsillar CD8 ${ }^{+} \mathrm{T}$ cell and salivary IgA responses in animals with lower viremia suggests an association between mucosal immunity and reduced virus replication. Alternatively, animals with higher viremia could have suffered more rapid loss of $\mathrm{CD}^{+} \mathrm{T}$ helper cells, which could have reduced SIVspecific immune responses.

\section{$\mathrm{CD4}^{+} \mathrm{T}$ cell loss in blood and tissues}

In infant macaques, the loss of $\mathrm{CD}^{+} \mathrm{T}$ cells due to SIV infection must be examined in relation to normal developmental changes in cell populations during the first few months of life. At birth, rhesus macaques, like humans [20-23], have very high frequencies of CD4 ${ }^{+} \mathrm{T}$ cells in blood and tissues when compared to CD8 $\mathrm{T}^{+}$cells. Within the first few months of life, the high CD4:CD8 $\mathrm{T}$ cell ratio decreases to approximate that in adults [11]. In the 
current study, the percentage of $\mathrm{CD} 4^{+} \mathrm{T}$ cells in blood of infants decreased from birth to one month of age, the time when they were challenged (Figure 7A). After SIV challenge and infection, both the percentages and absolute numbers of total $\mathrm{CD} 4^{+} \mathrm{T}$ cells in blood were relatively stable (Figure 7A and 7B). We did, however, observe a decrease in the frequencies of $\mathrm{CCR}^{+}$and $\mathrm{Ki} 67^{+} \mathrm{CD} 4^{+} \mathrm{T}$ cells in blood within the first 2 weeks of oral SIV infection (Figures 7C and 7D). This loss of activated blood $\mathrm{CD} 4^{+} \mathrm{T}$ cells was similar in vaccinated and naive control macaques after infection. At euthanasia, the loss of $\mathrm{CD}^{+} \mathrm{T}$ cells in various tissues was also comparable in vaccinated and unvaccinated macaques (Figure 8A). As expected, $\mathrm{CD}^{+} \mathrm{T}$ cell depletion was greatest $(>70 \%)$ in intestinal tissues [24]. In addition, we observed a marked loss of $\mathrm{CD}^{+} \mathrm{T}$ cells in the tonsil and in the submandibular LN draining the oral cavity, but not in the more distal axillary LN (Figure 8A). To confirm that the decline in tonsillar $\mathrm{CD} 4^{+} \mathrm{T}$ cells was due to SIV infection rather than age, $\mathrm{CD} 4^{+} \mathrm{T}$ cell frequencies in the infected macaques were compared to those in healthy 4-week or 11week old infant macaques that had not been vaccinated or challenged. The results clearly demonstrate that in addition to the age-related decline of $\mathrm{CD} 4^{+} \mathrm{T}$ cells, SIV infection caused further loss of $\mathrm{CD} 4^{+} \mathrm{T}$ cells in the tonsil (Figure 8A).

Consistent with the finding that infant intestinal tissues contain large numbers of $\mathrm{T}$ cells with a memory/activated phenotype [24], the main targets for SIV infection, we observed a drastic reduction of $\mathrm{CCR}^{+} \mathrm{CD}^{+} \mathrm{T}$ cells in the ileum and colon of the SIV-infected animals when compared to age-matched SIV naive infant macaques (Figure 8B). Due to large variation among animals, this difference reached statistical significance only in colonic tissue ( $\mathrm{P}<0.05$ compared to infected naive and vaccinated animals, respectively). Interestingly, the frequencies of $\mathrm{CCR} 5^{+} \mathrm{CD} 4^{+} \mathrm{T}$ cells in tonsils of the infected vaccine recipients and naive controls were not reduced despite the finding above that $\mathrm{CD} 4^{+} \mathrm{T}$ cells were depleted in the tonsil (Figure $8 \mathrm{~B}$ ). Thus, we examined the possibility that $\mathrm{CD} 4^{+} \mathrm{T}$ cell subsets were differentially depleted in the intestine versus tonsils of the infected animals. Despite the relatively low frequencies of $\mathrm{CCR}^{+} \mathrm{CD}^{+} \mathrm{T}$ cells in the tonsils, they contained a large proportion of $\mathrm{Ki} 67^{+}$and $\mathrm{CD} 25^{+}$activated $\mathrm{CD} 4^{+} \mathrm{T}$ cells, in frequencies similar to those in intestinal tissues (Figure 8B). Oral SIV infection reduced both intestinal $\mathrm{Ki}^{+} 7^{+}$and $\mathrm{CD} 25^{+} \mathrm{CD} 4^{+} \mathrm{T}$ cells, though only the loss of $\mathrm{CD} 25^{+} \mathrm{CD} 4^{+} \mathrm{T}$ cells reached significance (Figure 8B and C). In contrast, these cell populations did not decline in tonsils of SIVinfected animals. Among the markers analyzed, a significant depletion in tonsillar $\mathrm{CD}^{+} \mathrm{T}$ cells was only noted for the $\mathrm{CD} 25^{+} \mathrm{FoxP} 3^{+} \mathrm{CD} 4^{+} \mathrm{T}$ cell subset (Figure 8D). A loss of these cells was also observed in other tissues. It is noteworthy that in the tonsil and the mesenteric $\mathrm{LN}$, the loss of $\mathrm{CD} 25^{+} \mathrm{FoxP}^{+} \mathrm{CD}^{+}{ }^{\mathrm{T}}$ cells was lower in the vaccinated than naive control macaques (Figure 8D). These data suggest that in different tissues distinct $\mathrm{CD} 4^{+} \mathrm{T}$ cell populations might be preferentially depleted, and that $\mathrm{T}$ regulatory cells may be a major target of SIV infection in infant macaques.

\section{Discussion}

We previously demonstrated that an oral VSV-SIV prime/systemic MVA-SIV boost vaccine was able to induce local and systemic immune responses in mucosal and lymphoid tissues of infant macaques [13]. The current study tested the efficacy of this vaccine regimen for preventing oral SIV transmission in infant macaques.

Systemically administered prime-boost poxvirus-SIV vaccine strategies have shown partial efficacy against oral SIV challenge in the infant rhesus macaque model: only a third of ALVAC-SIV vaccinated infants became SIV-infected [12]. While infection with SIV was not prevented in most MVA-SIV and some ALVAC-SIV vaccinated infants, the SIVinfected vaccinated infants experienced reduced viremia and longer survival. Although the analysis of immune parameters was limited in these earlier studies, both SIV-specific 
antibody and $\mathrm{CD} 8^{+} \mathrm{T}$ cell responses were implicated in the control of virus replication. Low immunogenicity of ALVAC-SIV and limited protection of infant macaques after oral SIV exposure [12] are consistent with the modest protection observed in the recent ALVAC/ AIDSVAX HIV vaccine trial in adults in the absence of persistent $T$ cell responses [25].

To develop an improved neonatal vaccination strategy, we reasoned that oral administration of a pediatric SIV vaccine in combination with a systemic boost would be more efficient for preventing oral SIV transmission if it induced immune responses directly at the site of virus entry. The VSV vector was chosen because it has proved highly immunogenic in juvenile macaques and can be administered mucosally [26,27]. As we hypothesized, oral administration of VSV-SIV vaccine at birth followed by i.m. boosting with MVA-SIV at 2 weeks of age did induce SIV-specific mucosal and systemic immune responses in infant macaques [13]. However, in the current study, challenge of a new cohort of similarly vaccinated animals at 4 weeks of age using repeated oral SIV exposure to mimic breast milk transmission, did not prevent SIV transmission. Similar to our previous experience with MVA- and ALVAC-SIV pediatric SIV vaccines, the VSV-SIV/MVA-SIV regimen was only partly efficacious, based on the lower plasma viral RNA levels in vaccinated compared to unvaccinated infant macaques.

There are three main factors that could explain the lower efficacy of the VSV-SIV/MVASIV vaccine compared to our previous poxvirus only i.m. prime/boost strategies. First, reduced efficacy could be due to use of the different VSV priming viral vector or to priming by the oral route. Second, although the oral SIV challenge viruses used in this and previous studies were very similar, they were not identical. Challenge stocks for both studies were prepared from the same SIVmac251 seed stock (Table 2) and tested in adult animals to confirm infectivity $[28,29]$. Finally, in the current study, two naive and two vaccinated macaques did not become infected after the first round of oral SIV challenges. To ensure that all controls were infected, we re-challenged these 4 infants. Thus, the current SIV challenge regimen was more stringent than the previous single round challenge regimen. The re-challenged animals were 3 weeks older at the time of infection, and in the 2 vaccinated animals, the vaccine-induced immune responses would have had more time to mature. However, we consider it unlikely that the age difference at the time of challenge significantly influenced outcome. This assumption is based on the finding that in the 2 control animals, the later challenge did not influence viremia. The 2 rechallenged animals in the vaccine group were among the 4 that had relatively lower levels of viremia after infection. However, only 1 rechallenged vaccinated animal (\#39129) had SIV-specific plasma IgA at the time of the second challenge and developed SIV-specific tonsillar T cells after infection. The latter finding suggests that vaccine-induced immune responses were not consistently improved during the 3-week period between the first and second round of challenges.

In this study, animals were followed only for 2-3 months after challenge to assess tissue immune responses, and therefore a long-term effect of the vaccine on survival could not be tested. With this caveat in mind, several findings in the current study are potentially informative to the design and application of vaccine candidates in the future. First, at the time of challenge, SIV Env-specific IgA antibodies were detected in plasma of 6/8 vaccinated infant macaques, and these antibodies inversely correlated with peak viremia and viral load at 4 week post-challenge. This finding is consistent with our earlier study demonstrating that IgA antibodies, albeit at low levels, can be induced in infant macaques by this vaccine regimen [13]. Second, the vaccinated animals that had SIV-specific T cells in the tonsil and SIV-specific IgA in plasma and saliva after oral SIV challenge had the lowest levels of virus replication throughout the study. We cannot infer whether SIVspecific tonsillar $\mathrm{T}$ cells were present in the vaccinated infants at the time of challenge 
because tissue responses were evaluated only after challenge. In our previous study with VSV-SIV/MVA-SIV, 2 of 5 vaccinated infants tested for tonsil responses had detectable SIV-specific T cells at the week 4 time point [13]. Nevertheless, the postchallenge data here implies a potentially important role of mucosal responses in the control of virus replication. Finally, at the time of euthanasia, levels of SIV-specific IgA in plasma and salivary inversely correlated with viremia in the group of vaccinated macaques.

One could argue that the increased detection of SIV-specific humoral and cellular responses in VSV-SIV/MVA-SIV vaccinated animals compared to unvaccinated macaques reflected greater preservation of $\mathrm{CD}^{+} \mathrm{T}$ helper cell function after SIV infection. However, vaccinated infants that had SIV Env-specific IgA antibodies at the time of challenge, when $\mathrm{CD}^{+} \mathrm{T}$ cell populations did not differ in frequencies or activation markers, also had lower peak viremia after oral SIV challenge than unvaccinated macaques or the vaccinated infants without detectable SIV-specific IgA. This latter finding suggests that SIV-specific IgA itself might play a role in controlling virus replication after oral SIV challenge. However, it is more likely that the development of SIV-specific IgA is a surrogate marker that indirectly reflects the induction of immune responses that are needed for viral control. In this regard, the finding that SIV infection resulted in the depletion of regulatory $\mathrm{T}$ cells may be highly significant as these cells promote IgA responses [30].

Higher frequencies of central memory $\mathrm{CD} 4^{+} \mathrm{T}$ cells in the tonsils of vaccinated animals were also associated with lower viral load in blood. This finding is consistent with studies in adult SIV-infected macaques and HIV-1 infected humans showing that preservation of central memory $\mathrm{CD}^{+} \mathrm{T}$ cells correlates with better disease prognosis [31-35]. Considering that the tonsil is a primary site of virus replication after oral SIV challenge [11], the early local immune response in tonsils could affect long-term disease outcome. Knowledge concerning the cellular composition and milieu of the tonsil and how they influence virus replication is still limited. Our data provide some evidence that the target cell populations for SIV after oral exposure might differ between the tonsil and small intestine. Recently, $\mathrm{Ki} 67^{+} \mathrm{CD} 4^{+} \mathrm{T}$ cells have been identified as major target cells for infection in infant macaques intravenously infected with SIV [36]. Our data confirm that the tonsil and intestine, sites of primary virus replication after oral SIV infection, contain higher frequencies of $\mathrm{Ki} 67^{+} \mathrm{CD} 4^{+} \mathrm{T}$ cells than other lymphoid tissues in infant macaques. While the decline of $\mathrm{Ki}_{67}{ }^{+} \mathrm{CD} 4^{+} \mathrm{T}$ cells after oral SIV challenge did not reach statistical significance, due to the large animal-to-animal variation, the higher frequencies of Ki67 ${ }^{+}$ $\mathrm{CD} 4^{+} \mathrm{T}$ cells in infant compared to adult macaques (Abel, unpublished data) likely provide a greater pool of target cells for the virus.

The frequencies of CCR5 ${ }^{+} \mathrm{CD} 4^{+} \mathrm{T}$ cells in the tonsil were significantly lower than the frequencies of $\mathrm{CCR}^{+} \mathrm{CD}^{+} \mathrm{T}$ cells in intestinal tissues, and more similar to frequencies observed in lymph nodes. Consistent with this observation, a significant loss of CCR5 $5^{+}$ $\mathrm{CD}^{+} \mathrm{T}$ cells after oral SIV challenge was observed in intestinal tissues, but not in the tonsil. The severe loss of $\mathrm{CD} 4^{+} \mathrm{T}$ cells in tonsils after oral SIV infection appeared to be due to diminished frequencies of $\mathrm{CD} 25^{+} \mathrm{FoxP} 3^{+} \mathrm{CD} 4^{+} \mathrm{T}$ cells. This data is consistent with recent studies showing a loss of Treg cells in pathogenic SIV infection [37,38], and in HIV-1 infected patients [39]. Thus, future studies should test whether SIV may preferentially infect or result in the loss of distinct $\mathrm{CD} 4^{+} \mathrm{T}$ cell populations in different anatomic compartments. A better understanding of the unique anatomic, cellular and immunological parameters of the distinct tissues that serve as primary entry sites for the virus and are the portal for dissemination is required for the development of a successful pediatric HIV vaccine to prevent breast milk transmission. 
In summary, the oral VSV-SIV prime/ intramuscular MVA-SIV boost regimen did not prevent oral SIV infection in infant macaques. Although the group of vaccinated animals showed more consistent local and systemic immune responses compared to the unvaccinated animals, a precise immunological correlate associated with reduced viremia was not identified as tissue-specific immune responses and mucosal $\operatorname{IgA}$ at the time of challenge were not assessed. After oral SIV challenge, the data indicate that virus replication is best controlled in animals with both local and systemic antiviral IgA antibodies and with locally induced SIV-specific $\mathrm{T}$ cell responses. We therefore propose that novel vaccine strategies should aim at enhancing these local immune responses at mucosal sites of viral entry using mucosal adjuvants and immune modulators.

\section{Acknowledgments}

This work was supported by the NIH/NIAID grant R01 AI062518 to MM, and, in part, by the Louisiana Vaccine Center and the South Louisiana Institute for Infectious Disease Research sponsored by the Louisiana Board of Regents. The animal studies at the CNPRC were supported by grant RR00169 from the National Center for Research Resources (NCRR; a component of the National Institutes of Health (NIH). SIVmac251 was obtained from the Analytical Core of the CNPRC. The SIV gag peptide pool was from the AIDS Research and Reference Reagent Program (Division of AIDS, NIAID, NIH). Dr. Jeff Lifson (AIDS and Cancer Virus Program, National Cancer Institute at Frederick, Frederick, MD) provided aldrithiol-2 inactivated SIVmac239 particles. We also thank the Qualitative Molecular Diagnostics Core of the AIDS Vaccine Program at SAIC Frederick/ NCI for assistance with the quantitation of plasma viral RNA. In addition, we are indebted to the veterinary staff at the CNPRC, and would like to thank Yongzhi Geng and Robert L. Wilson for technical assistance in the studies, and Jeffrey Americo for preparation of the MVA viruses. The contents of this publication though are solely the responsibility of the authors and do not necessarily represent the official views of NCRR or NIH.

\section{References}

1. Mofenson LM. Antiretroviral drugs to prevent breastfeeding HIV transmission. Antivir Ther. 15(4): 537-53. [PubMed: 20587847]

2. Mofenson LM. Protecting the next generation--eliminating perinatal HIV-1 infection. N Engl J Med. Jun 17; 362(24):2316-8. [PubMed: 20554987]

3. Zolfo M, De Weggheleire A, Schouten E, Lynen L. Time for "test and treat" in prevention of mother-to-child transmission programs in low- and middle-income countries. J Acquir Immune Defic Syndr. Nov 1; 55(3):287-9. [PubMed: 20714271]

4. Marazzi MC, Liotta G, Nielsen-Saines K, Haswell J, Magid NA, Buonomo E, et al. Extended antenatal antiretroviral use correlates with improved infant outcomes throughout the first year of life. AIDS. Nov 27; 24(18):2819-26. [PubMed: 20885282]

5. van der Horst C, Chasela C, Ahmed Y, Hoffman I, Hosseinipour M, Knight R, et al. Modifications of a large HIV prevention clinical trial to fit changing realities: a case study of the Breastfeeding, Antiretroviral, and Nutrition (BAN) protocol in Lilongwe, Malawi. Contemp Clin Trials. 2009 Jan; 30(1):24-33. [PubMed: 18805510]

6. Abel K. The rhesus macaque pediatric SIV infection model - a valuable tool in understanding infant HIV-1 pathogenesis and for designing pediatric HIV-1 prevention strategies. Curr HIV Res. 2009 Jan; 7(1):2-11. [PubMed: 19149549]

7. Luzuriaga K. Mother-to-child transmission of HIV: a global perspective. Curr Infect Dis Rep. 2007 Nov; 9(6):511-7. [PubMed: 17999887]

8. Luzuriaga K, Newell ML, Dabis F, Excler JL, Sullivan JL. Vaccines to prevent transmission of HIV-1 via breastmilk: scientific and logistical priorities. Lancet. 2006 Aug 5; 368(9534):511-21. [PubMed: 16890838]

9. Marthas ML, Miller CJ. Developing a neonatal HIV vaccine: insights from macaque models of pediatric HIV/AIDS. Curr Opin HIV AIDS. 2007 Sep; 2(5):367-74. [PubMed: 19372914]

10. Safrit JT. HIV vaccines in infants and children: past trials, present plans and future perspectives. Curr Mol Med. 2003 May; 3(3):303-12. [PubMed: 12699365] 
11. Abel K, Pahar B, Van Rompay KK, Fritts L, Sin C, Schmidt K, et al. Rapid virus dissemination in infant macaques after oral simian immunodeficiency virus exposure in the presence of local innate immune responses. J Virol. 2006 Jul; 80(13):6357-67. [PubMed: 16775324]

12. Van Rompay KK, Abel K, Lawson JR, Singh RP, Schmidt KA, Evans T, et al. Attenuated poxvirus-based simian immunodeficiency virus (SIV) vaccines given in infancy partially protect infant and juvenile macaques against repeated oral challenge with virulent SIV. J Acquir Immune Defic Syndr. 2005 Feb 1; 38(2):124-34. [PubMed: 15671796]

13. Van Rompay K, Abel K, Earl P, Kozlowski PA, Easlick J, Moore JP, et al. Immunogenicity of viral vector, prime -boost SIV vaccine regimens in infant rhesus macaques: attenuated vesicular stomatitis virus (VSV) and modified vaccinia Ankara (MVA) recombinant SIV vaccines compared to live-attenuated SIV. Vaccine. 2010; 28(6):1481-92. [PubMed: 19995539]

14. Van Rompay KK, Schmidt KA, Lawson JR, Singh R, Bischofberger N, Marthas ML. Topical administration of low-dose tenofovir disoproxil fumarate to protect infant macaques against multiple oral exposures of low doses of simian immunodeficiency virus. J Infect Dis. 2002 Nov 15; 186(10):1508-13. [PubMed: 12404171]

15. Earl PL, Wyatt LS, Montefiori DC, Bilska M, Woodward R, Markham PD, et al. Comparison of vaccine strategies using recombinant env-gag-pol MVA with or without an oligomeric Env protein boost in the SHIV rhesus macaque model. Virology. 2002 Mar 15; 294(2):270-81. [PubMed: 12009868]

16. Kozlowski PA, Lynch RM, Patterson RR, Cu-Uvin S, Flanigan TP, Neutra MR. Modified wick method using Weck-Cel sponges for collection of human rectal secretions and analysis of mucosal HIV antibody. J Acquir Immune Defic Syndr. 2000 Aug 1; 24(4):297-309. [PubMed: 11015145]

17. Manrique M, Kozlowski PA, Wang SW, Wilson RL, Micewicz E, Montefiori DC, et al. Nasal DNA-MVA SIV vaccination provides more significant protection from progression to AIDS than a similar intramuscular vaccination. Mucosal Immunol. 2009 Nov; 2(6):536-50. [PubMed: 19741603]

18. Cline AN, Bess JW, Piatak M Jr, Lifson JD. Highly sensitive SIV plasma viral load assay: practical considerations, realistic performance expectations, and application to reverse engineering of vaccines for AIDS. J Med Primatol. 2005 Oct; 34(5-6):303-12. [PubMed: 16128925]

19. Sun Y, Permar SR, Buzby AP, Letvin NL. Memory CD4+ T-lymphocyte loss and dysfunction during primary simian immunodeficiency virus infection. J Virol. 2007 Aug; 81(15):8009-15. [PubMed: 17522197]

20. Erkeller-Yuksel FM, Deneys V, Yuksel B, Hannet I, Hulstaert F, Hamilton C, et al. Age-related changes in human blood lymphocyte subpopulations. J Pediatr. 1992 Feb; 120(2 Pt 1):216-22. [PubMed: 1735817]

21. Shahabuddin S, Al-Ayed I, Gad El-Rab MO, Qureshi MI. Age-related changes in blood lymphocyte subsets of Saudi Arabian healthy children. Clin Diagn Lab Immunol. 1998 Sep; 5(5): 632-5. [PubMed: 9729529]

22. Shahabuddin S, al Ayed IH, el-Rad MO, Qureshi MI. Lymphocyte subset reference ranges in healthy Saudi Arabian children. Pediatr Allergy Immunol. 1998 Feb; 9(1):44-8. [PubMed: 9560843]

23. Shearer WT, Rosenblatt HM, Gelman RS, Oyomopito R, Plaeger S, Stiehm ER, et al. Lymphocyte subsets in healthy children from birth through 18 years of age: the Pediatric AIDS Clinical Trials Group P1009 study. J Allergy Clin Immunol. 2003 Nov; 112(5):973-80. [PubMed: 14610491]

24. Wang X, Rasmussen T, Pahar B, Poonia B, Alvarez X, Lackner AA, et al. Massive infection and loss of CD4+ T cells occurs in the intestinal tract of neonatal rhesus macaques in acute SIV infection. Blood. 2007 Feb 1; 109(3):1174-81. [PubMed: 17047153]

25. Rerks-Ngarm S, Pitisuttithum P, Nitayaphan S, Kaewkungwal J, Chiu J, Paris R, et al. Vaccination with ALVAC and AIDSVAX to prevent HIV-1 infection in Thailand. N Engl J Med. 2009 Dec 3; 361(23):2209-20. [PubMed: 19843557]

26. Clarke DK, Nasar F, Lee M, Johnson JE, Wright K, Calderon P, et al. Synergistic attenuation of vesicular stomatitis virus by combination of specific $\mathrm{G}$ gene truncations and $\mathrm{N}$ gene translocations. J Virol. 2007 Feb; 81(4):2056-64. [PubMed: 17151112] 
27. Egan MA, Chong SY, Rose NF, Megati S, Lopez KJ, Schadeck EB, et al. Immunogenicity of attenuated vesicular stomatitis virus vectors expressing HIV type 1 Env and SIV Gag proteins: comparison of intranasal and intramuscular vaccination routes. AIDS Res Hum Retroviruses. 2004 Sep; 20(9):989-1004. [PubMed: 15585086]

28. Marthas ML, Lu D, Penedo MC, Hendrickx AG, Miller CJ. Titration of an SIVmac251 stock by vaginal inoculation of Indian and Chinese origin rhesus macaques: transmission efficiency, viral loads, and antibody responses. AIDS Res Hum Retroviruses. 2001 Oct 10; 17(15):1455-66. [PubMed: 11679158]

29. Alpert MD, Rahmberg AR, Neidermyer W, Ng SK, Carville A, Camp JV, et al. Envelope-modified single-cycle simian immunodeficiency virus selectively enhances antibody responses and partially protects against repeated, low-dose vaginal challenge. J Virol. 2010 Oct; 84(20):10748-64. [PubMed: 20702641]

30. Feng T, Elson CO. Adaptive immunity in the host-microbiota dialog. Mucosal Immunol. 2011 Jan; 4(1):15-21. [PubMed: 20944557]

31. Kelleher AD, Zaunders JJ. Decimated or missing in action: CD4+ T cells as targets and effectors in the pathogenesis of primary HIV infection. Curr HIV/AIDS Rep. 2006 Feb; 3(1):5-12. [PubMed: 16522253]

32. Mattapallil JJ, Letvin NL, Roederer M. T-cell dynamics during acute SIV infection. AIDS. 2004 Jan 2; 18(1):13-23. [PubMed: 15090825]

33. Verhoeven D, Sankaran S, Silvey M, Dandekar S. Antiviral therapy during primary simian immunodeficiency virus infection fails to prevent acute loss of CD4+ T cells in gut mucosa but enhances their rapid restoration through central memory T cells. J Virol. 2008 Apr; 82(8):401627. [PubMed: 18272585]

34. Zaunders JJ, Dyer WB, Munier ML, Ip S, Liu J, Amyes E, et al. CD127+CCR5+CD38+++CD4+ Th1 effector cells are an early component of the primary immune response to vaccinia virus and precede development of interleukin-2+ memory CD4+ T cells. J Virol. 2006 Oct; 80(20):1015161. [PubMed: 17005692]

35. Zaunders JJ, Ip S, Munier ML, Kaufmann DE, Suzuki K, Brereton C, et al. Infection of CD127+ (interleukin-7 receptor+) CD4+ cells and overexpression of CTLA-4 are linked to loss of antigenspecific CD4 T cells during primary human immunodeficiency virus type 1 infection. J Virol. 2006 Oct; 80(20):10162-72. [PubMed: 17005693]

36. Wang X, Xu H, Pahar B, Alvarez X, Green LC, Dufour J, et al. Simian immunodeficiency virus selectively infects proliferating CD4+ T cells in neonatal rhesus macaques. Blood. 2010 Nov 18; 116(20):4168-74. [PubMed: 20716768]

37. Chase AJ, Sedaghat AR, German JR, Gama L, Zink MC, Clements JE, et al. Severe depletion of $\mathrm{CD} 4+\mathrm{CD} 25+$ regulatory $\mathrm{T}$ cells from the intestinal lamina propria but not peripheral blood or lymph nodes during acute simian immunodeficiency virus infection. J Virol. 2007 Dec; 81(23): 12748-57. [PubMed: 17855517]

38. Qin S, Sui Y, Soloff AC, Junecko BA, Kirschner DE, Murphey-Corb MA, et al. Chemokine and cytokine mediated loss of regulatory $\mathrm{T}$ cells in lymph nodes during pathogenic simian immunodeficiency virus infection. J Immunol. 2008 Apr 15; 180(8):5530-6. [PubMed: 18390737]

39. Dunham RM, Cervasi B, Brenchley JM, Albrecht H, Weintrob A, Sumpter B, et al. CD127 and CD25 expression defines CD4+ T cell subsets that are differentially depleted during HIV infection. J Immunol. 2008 Apr 15; 180(8):5582-92. [PubMed: 18390743]

40. Van Rompay KK, Berardi CJ, Dillard-Telm S, Tarara RP, Canfield DR, Valverde CR, et al. Passive immunization of newborn rhesus macaques prevents oral simian immunodeficiency virus infection. J Infect Dis. 1998 May; 177(5):1247-59. [PubMed: 9593009]

41. Van Rompay KK, Greenier JL, Cole KS, Earl P, Moss B, Steckbeck JD, et al. Immunization of newborn rhesus macaques with simian immunodeficiency virus (SIV) vaccines prolongs survival after oral challenge with virulent SIVmac251. J Virol. 2003 Jan; 77(1):179-90. [PubMed: 12477823]

42. Greenier JL, Miller CJ, Lu D, Dailey PJ, Lu FX, Kunstman KJ, et al. Route of simian immunodeficiency virus inoculation determines the complexity but not the identity of viral variant populations that infect rhesus macaques. J Virol. 2001 Apr; 75(8):3753-65. [PubMed: 11264364] 
A

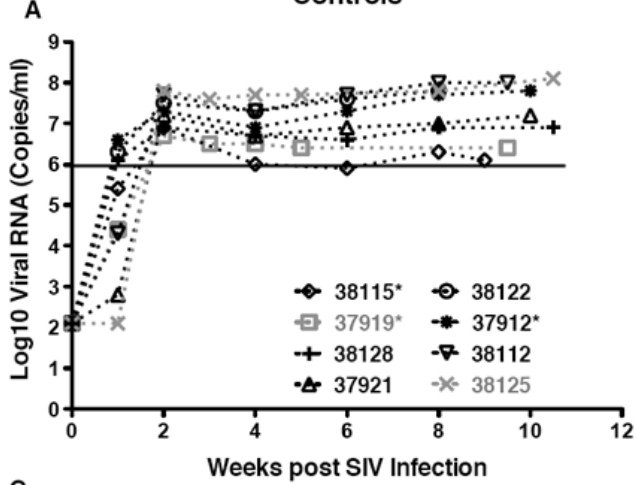

C

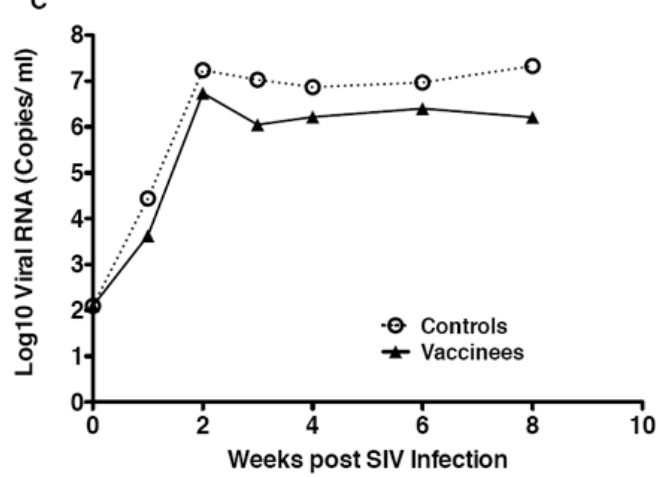

B
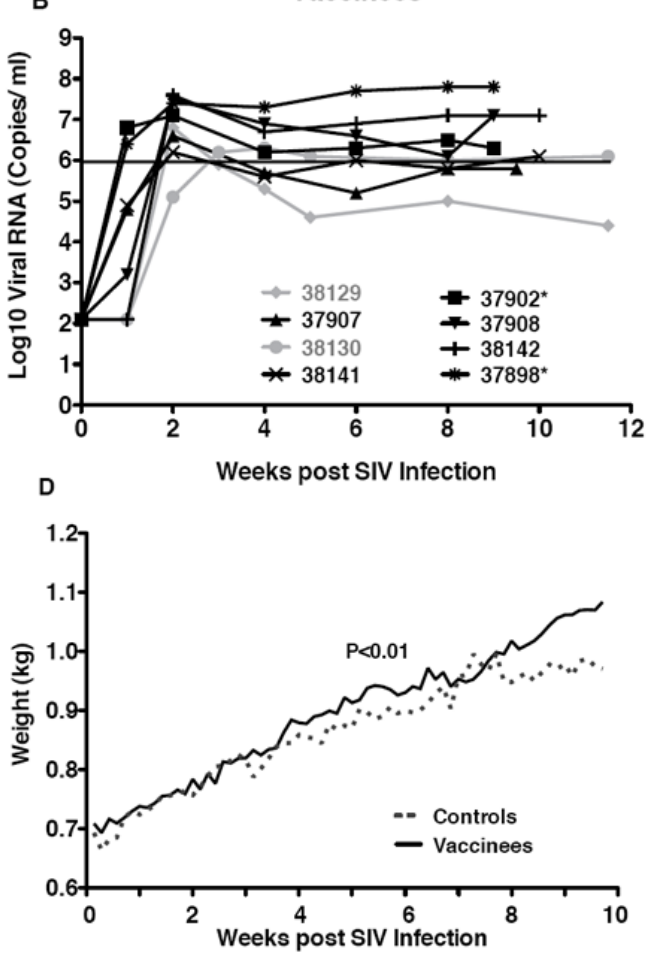

Figure 1.

Plasma viremia and weight gain. Panels A and B show the longitudinal SIV viral levels in the plasma of unvaccinated and vaccinated macaques, respectively. Each symbol depicts an individual animal. The animals that were given a second round of challenges are shown in gray. Mamu $A * 01$ positive animals are marked with an asteriks. Data are shown in relation to weeks post-infection (x-axis), and therefore all animals start at week 0 . The black line marks the lower limit of SIV replication (10^6) at viral set point measured in unvaccinated macaques. Panel C: Geometric means of SIV virus levels in unvaccinated (open symbol, dashed line) compared to vaccinated macaques (closed symbol, solid line) in the first 8 weeks after SIV infection. Panel D: The average weight gain for unvaccinated (dashed line) and vaccinated macaques (solid line) after SIV infection. The $\mathrm{P}$ value of $<0.01$ was obtained by regression analysis. 

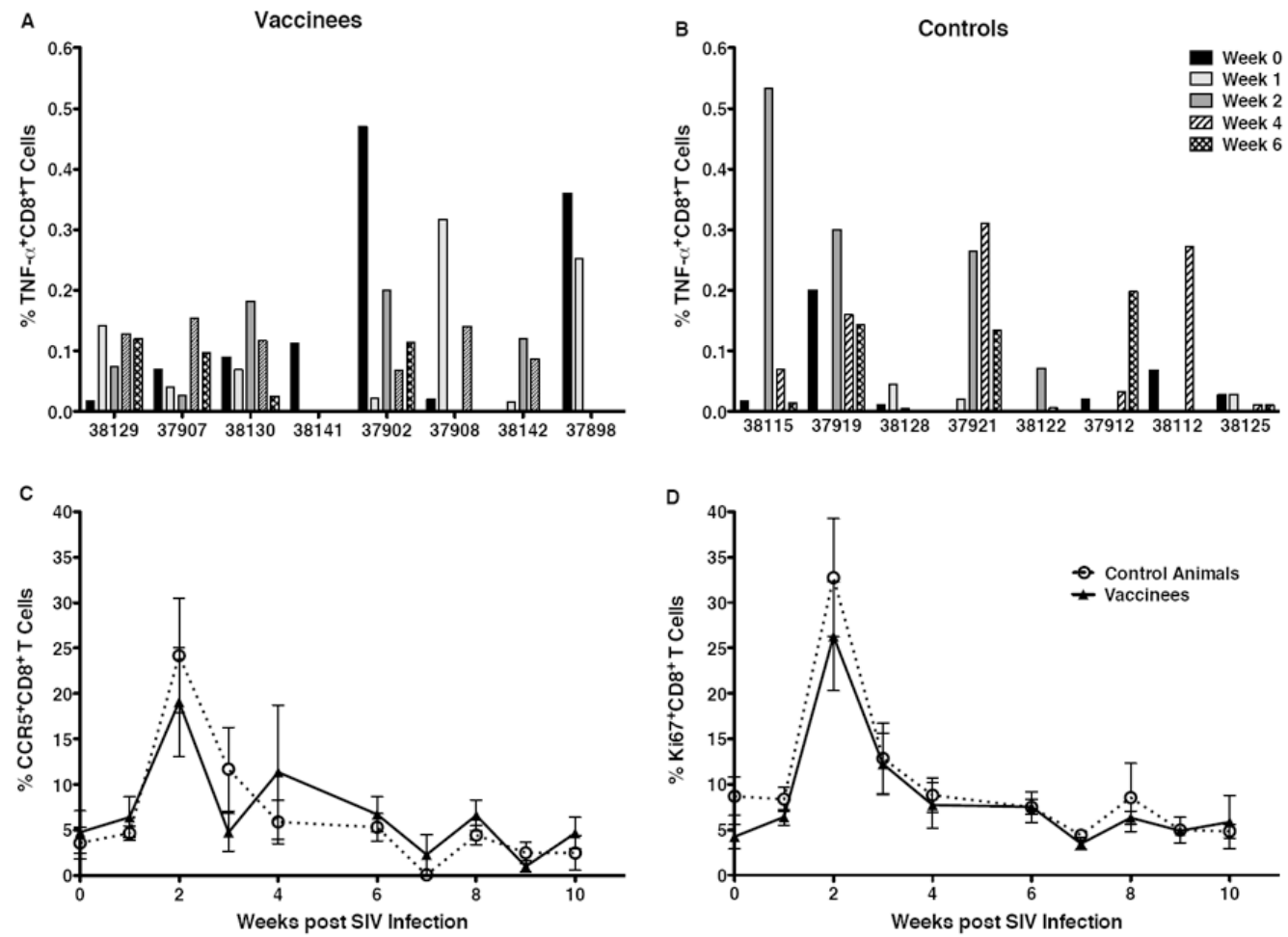

Figure 2.

$\mathrm{T}$ cell activation and SIV-specific $\mathrm{CD} 8^{+} \mathrm{T}$ cells in blood after SIV challenge. Panels A and B show the sum of the percentages of TNF- $\alpha$ producing $\mathrm{CD} 8^{+} \mathrm{T}$ cells after in vitro stimulation with a SIV Gag p27 peptide pool and with AT-2 inactivated SIVmac239 in vaccinated and unvaccinated macaques, respectively, in the first 6 weeks after SIV challenge. The average frequencies of $\mathrm{CCR}^{+}$(Panel C) and $\mathrm{Ki} 67^{+} \mathrm{CD}^{+} \mathrm{T}$ cells (Panel D) in peripheral blood of vaccinated (closed symbol, solid line) and unvaccinated (open symbol, dashed line) macaques over time are presented. 
A
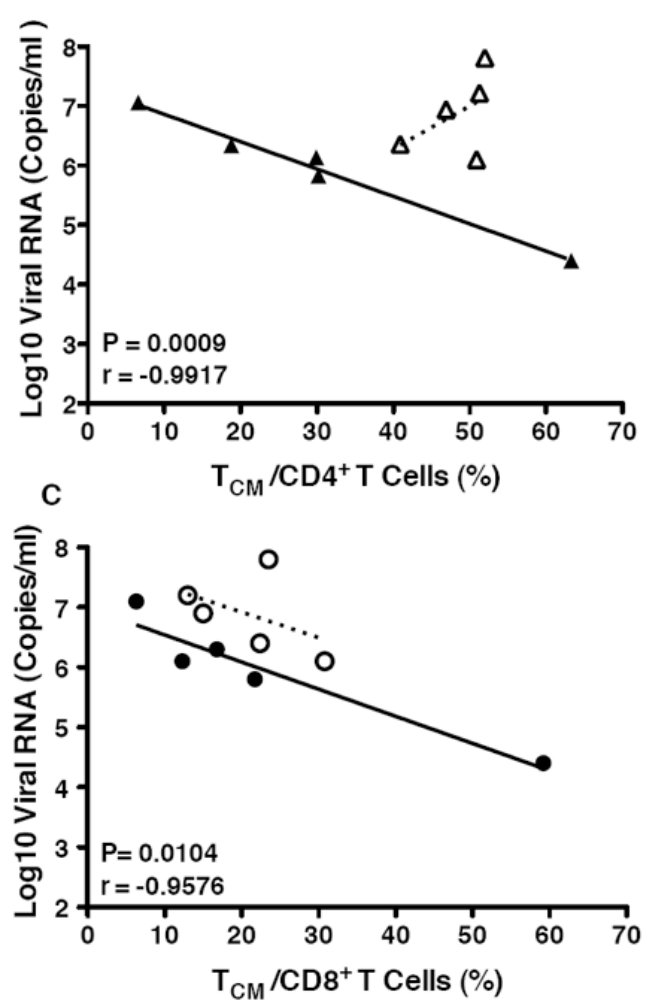

B
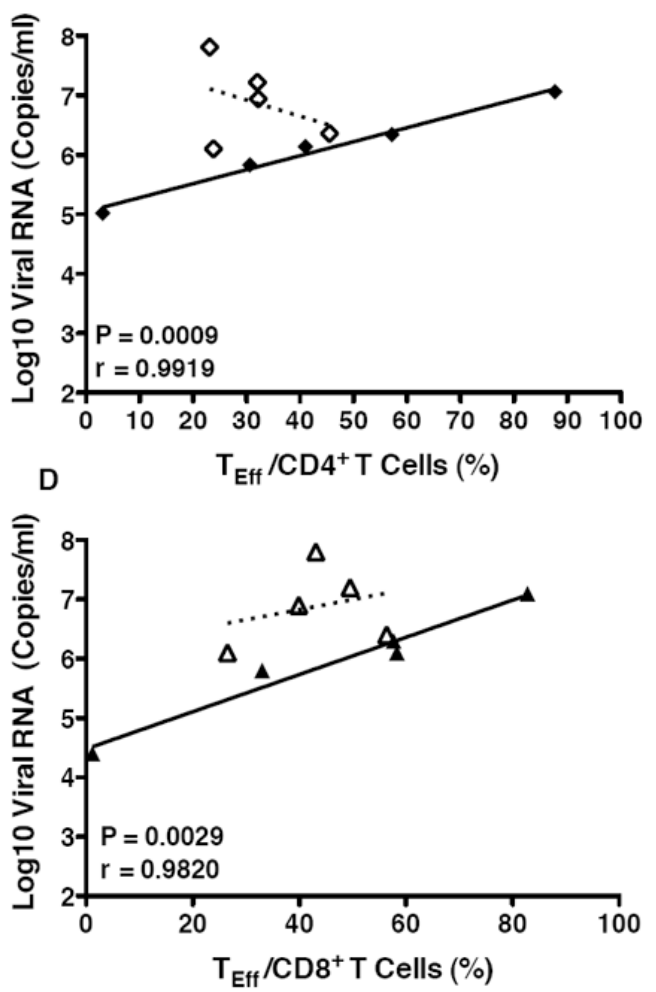

Figure 3.

Correlations between tonsil $\mathrm{CD}^{+}$and $\mathrm{CD}^{+}$memory $\mathrm{T}$ cell populations and plasma viral load at euthanasia. The percentages of central memory $\left(\mathrm{T}_{\mathrm{CM}}\right)$ (Panels $\mathrm{A}$ and $\mathrm{C}$ ) and effector/ effector memory $\mathrm{T}$ cells $\left(\mathrm{T}_{\mathrm{Eff}}\right.$; Panels B and $\mathrm{D}$ ) within the $\mathrm{CD} 4^{+}$(Panels A and B) or $\mathrm{CD}^{+} \mathrm{T}$ cell population (Panels $\mathrm{C}$ and $\mathrm{D}$ ) of the tonsils of vaccinated (closed symbols) and unvaccinated (open symbols) macaques are plotted against the SIV RNA copies per $\mathrm{ml}$ of plasma in the same animals at the time of euthanasia. Note that correlations were only statistically significant for vaccinated animals, and the $\mathrm{P}$ values and correlation coefficients are presented in each of the graphs. Due to limited cell numbers, data were only available for 5 of the 8 animals in each group (see text). 


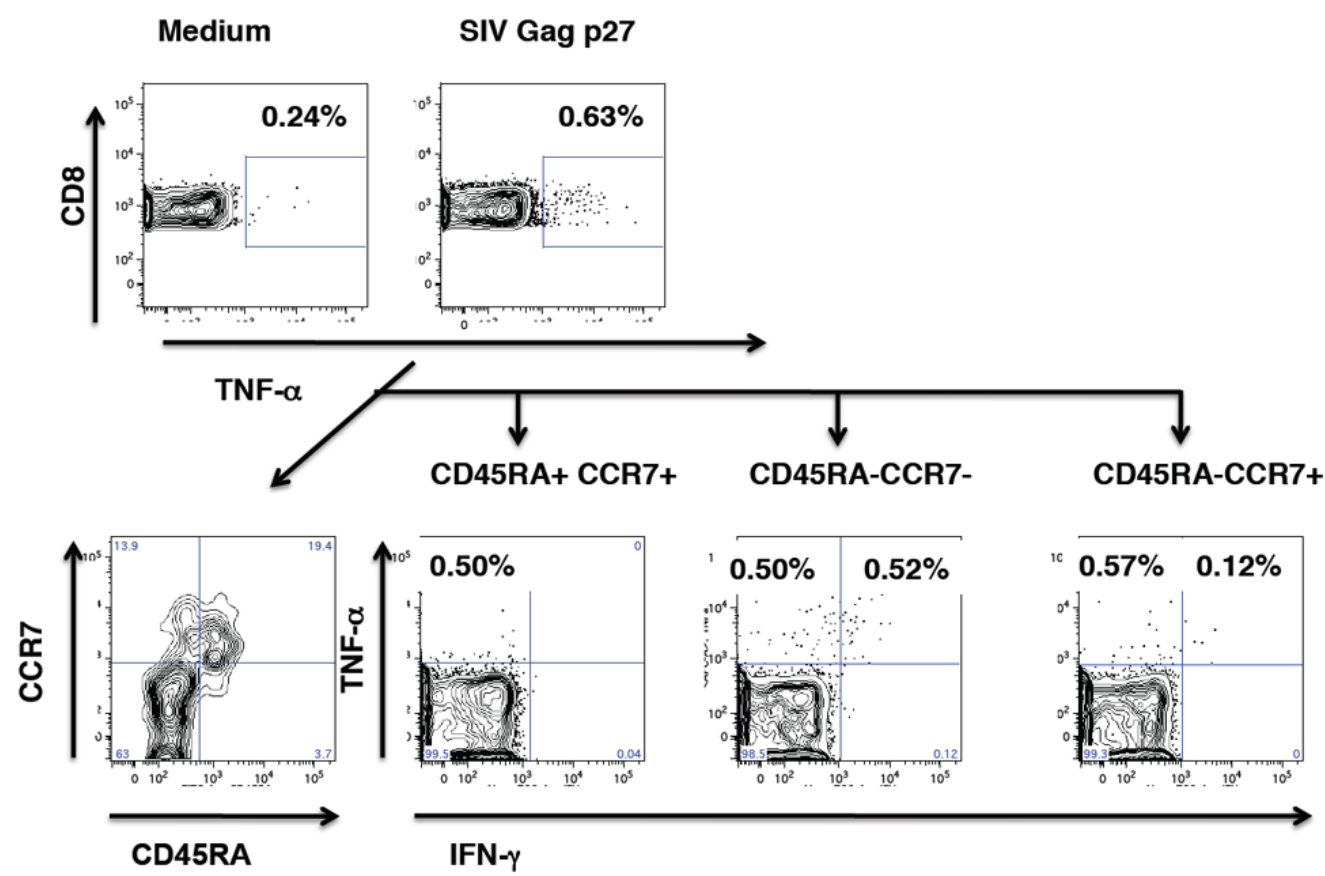

Figure 4.

Cytokine-producing SIV-specific $\mathrm{CD}^{+} \mathrm{T}$ cells in the tonsil of a vaccinated animal. Top panel: Frequencies of TNF- $\alpha$ producing $\mathrm{CD}^{+} \mathrm{T}$ cells in medium and in SIVgag p27

stimulated cells. The SIV-specific TNF- $\alpha$ producing $\mathrm{CD}^{+} \mathrm{T}$ cells were then further analyzed (bottom panels) to determine their differentiation status. The first plot shows the overall distribution of naïve $\left(\mathrm{CD}^{2} 5 \mathrm{RA}^{+} \mathrm{CCR}^{+}\right)$, central memory $\left(\mathrm{CD} 45 \mathrm{RA}^{-} \mathrm{CCR} 7^{+}\right.$) and effector/ effector memory (CD45RA $\left.{ }^{+/-} \mathrm{CCR}^{-}\right) \mathrm{TNF}-\alpha$ producing $\mathrm{CD}^{+} \mathrm{T}$ cells. The majority of TNF$\alpha$ producing cells were found in the effector/ effector memory $\mathrm{T}$ cell population. 
Figure 5.
A

Vaccinees

$\lg G$

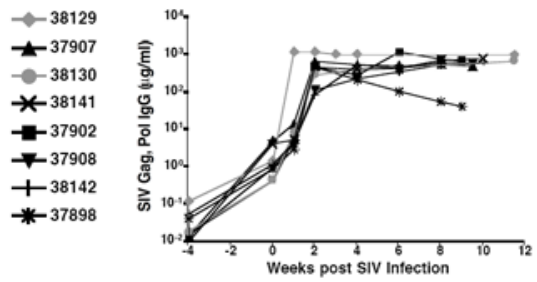

Controls

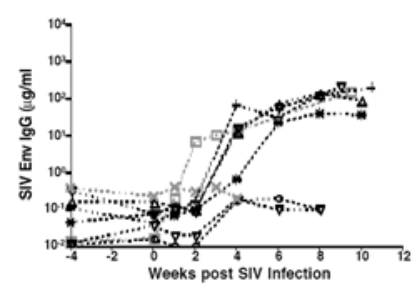

-0.38115

- 조. 37919

$\cdot+37921$

$\cdot \mathbf{A} \cdot 37921$
$-\mathbf{0} \cdot 38122$

-*.37912

$\cdot \boldsymbol{\nabla} \cdot 38112$

$-3 \cdot 38125$

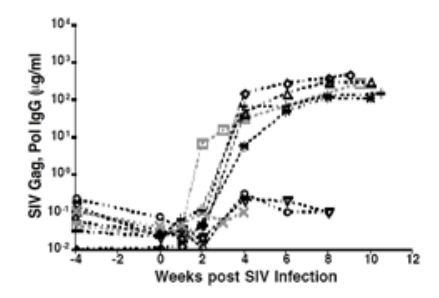

$\lg A$

\section{Vaccinees}

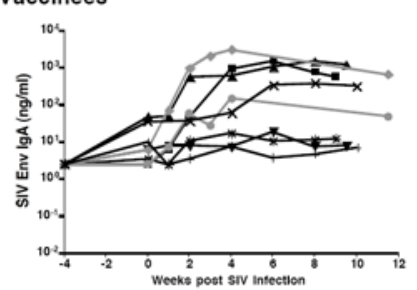

Controls

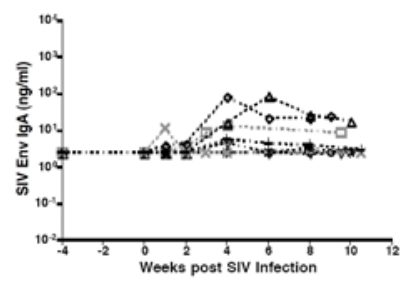

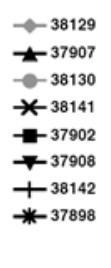

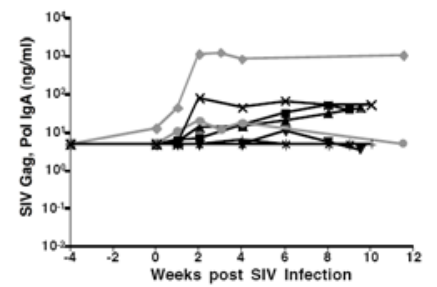

-๑. 38115

- 지. 37919

$\cdot+\cdot 38128$

-4.37921

:- $\cdot 38122$

-*.*3.37912

- $\times \cdot 38125$

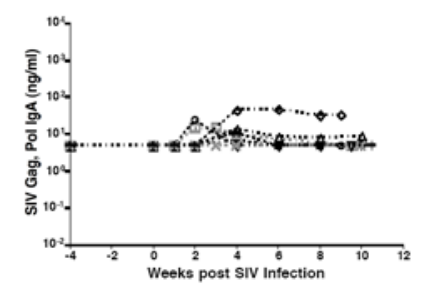

Longitudinal SIV-specific plasma IgG and IgA antibodies. Panel A: Shown are the concentrations of IgA (Panel A) and IgA (Panel B) antibodies against SIV Env (left) and SIV Gag, Pol (right) proteins measured by ELISA in plasma of each vaccinated and unvaccinated macaque before and after oral SIV challenge. 

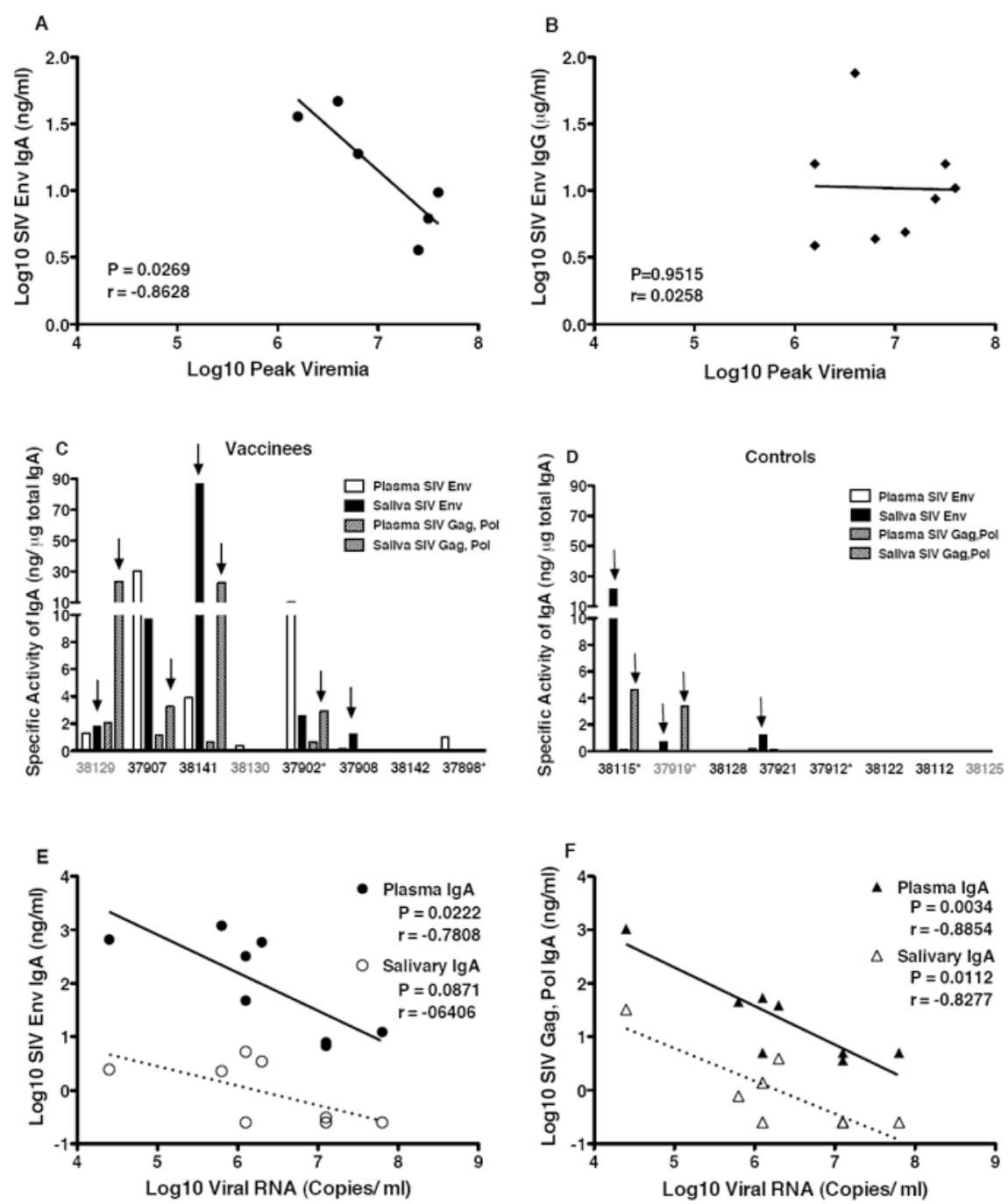

Figure 6.

Correlation between SIV-specific antibodies and SIV replication levels. In Panel A and Panel B the correlation between peak plasma viremia and SIV Env-specific plasma IgA and $\mathrm{IgG}$ antibodies, respectively, at the time of challenge in vaccinated macaques is shown. Note that the two animals that did not develop SIV Env-specific IgA antibodies (\#37902, \#38130) were not included in Panel A, while Panel B includes all 8 vaccinees. Note that no correlation between plasma SIV-specific IgG antibody levels at the time of challenge and peak viremia was observed independent of whether all 8 vaccinees (see Panel B) or only the 6 vaccinated macaques $(\mathrm{P}=0.5472, \mathrm{r}=-0.312)$ shown in Panel A were included in the analysis. In Panels $\mathrm{C}$ and D the specific activity (ng anti-SIV $\operatorname{IgA}$ antibody per $\mu \mathrm{g}$ total $\operatorname{IgA}$ ) in plasma and saliva of each individual animal at the time of euthanasia is shown for vaccinated (C) and unvaccinated (D) animals. Animals with lowest to highest viremia are presented from left to right. Arrows denote salivary specimens that had specific activity than plasma from the same animal. Panels $\mathrm{E}$ and $\mathrm{F}$ demonstrate the inverse correlation between viral load and SIV Env (E) or SIV Gag, Pol (Panel F) IgA concentration in plasma or saliva of vaccinated animals at the time of euthanasia. 
A
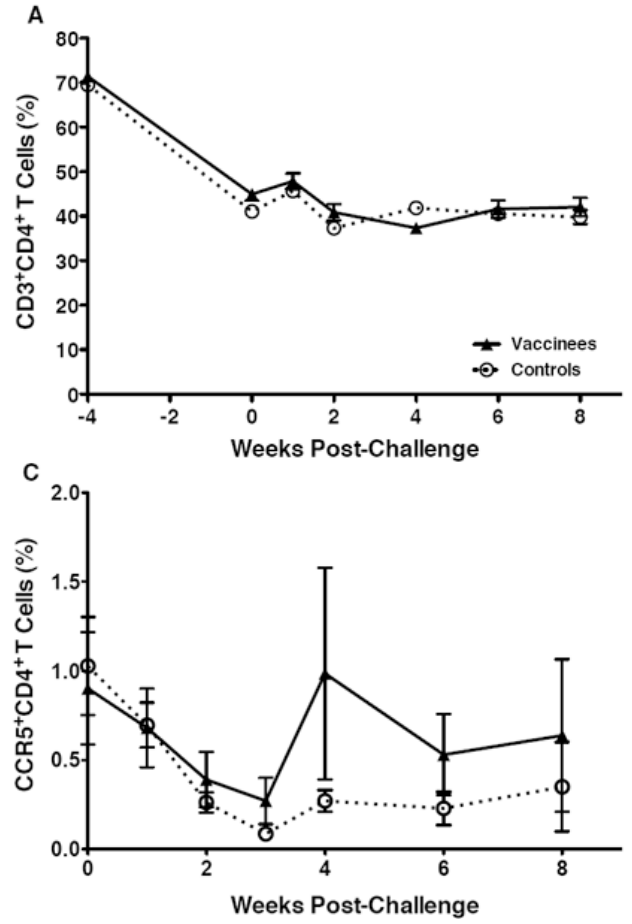

B
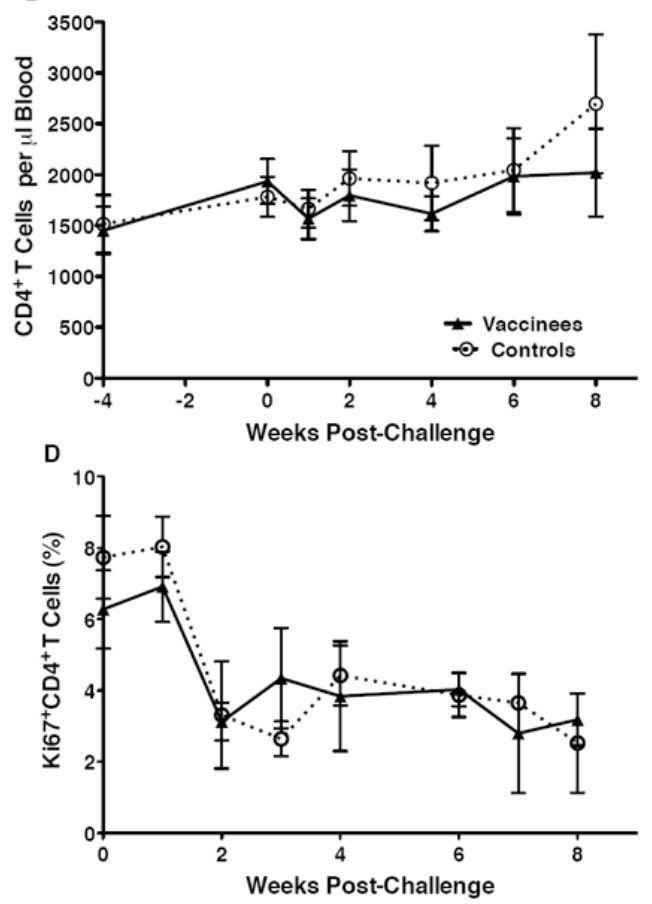

Figure 7.

$\mathrm{CD} 4^{+} \mathrm{T}$ cell frequencies and activation in peripheral blood. Panel A and Panel B show the average percentages of $\mathrm{CD}^{+} \mathrm{CD}^{+} \mathrm{T}$ cells within PBMC and the absolute numbers of $\mathrm{CD}^{+}{ }^{+} \mathrm{CD} 4^{+} \mathrm{T}$ cells per microliter of blood, respectively, in peripheral blood of vaccinated and unvaccinated macaques. In Panels $\mathrm{C}$ and $\mathrm{D}$, the change in the frequencies of CCR5 ${ }^{+}$ (Panel C) or $\mathrm{Ki}^{+} 7^{+}$(Panel D) $\mathrm{CD}^{+} \mathrm{T}$ cells after oral SIV infection are shown. Average values for vaccinated and unvaccinated macaques are presented with SEM. 
A

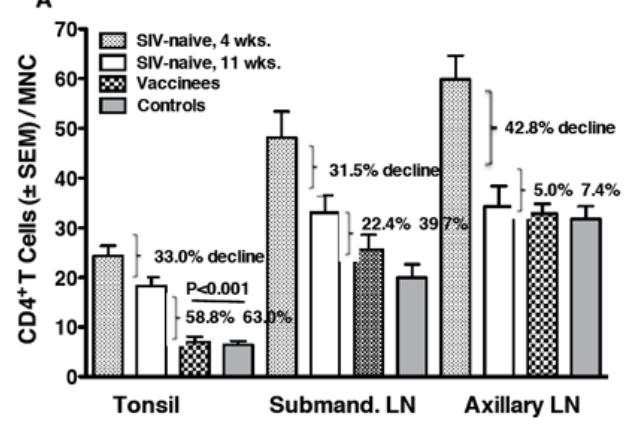

C

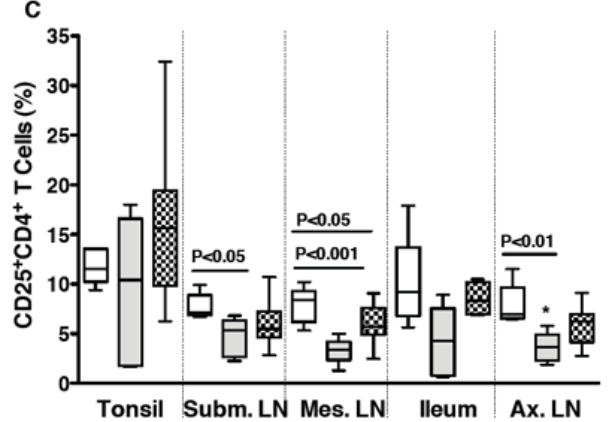

B

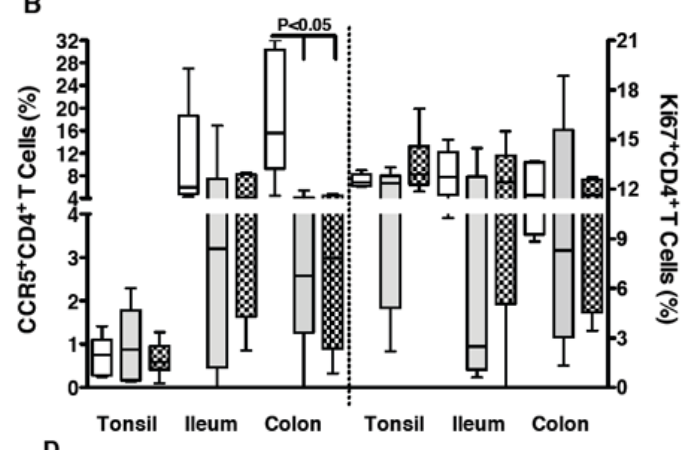

D

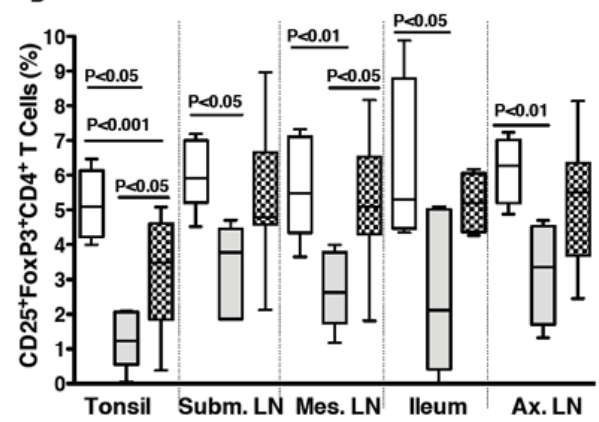

Figure 8.

Activation and loss of $\mathrm{CD}^{+}{ }^{+} \mathrm{T}$ cells in tissues. Panel A: Shown are average percentages of $\mathrm{CD} 4^{+} \mathrm{T}$ cells within mononuclear cell populations from different tissues of age-matched (11 weeks) SIV-naïve (empty bars), unvaccinated (gray bars) and vaccinated macaques (dotted bars) at the time of euthanasia in comparison to the normal age-related decline of $\mathrm{CD}^{+} \mathrm{T}$ cells in these tissues (week 4 to week 11 of age). Panel B shows the loss of activated CCR5 or Ki67-positive $\mathrm{CD}^{+} \mathrm{T}$ cells, respectively, in tonsil and intestinal tissues of age-matched SIV-naïve (empty bars), in unvaccinated (gray bars) and in vaccinated macaques (dotted bars) at the time of euthanasia. In Panel $\mathrm{C}$ and Panel $\mathrm{D}$ the loss of $\mathrm{CD} 25^{+} \mathrm{CD} 4^{+} \mathrm{T}$ cells and $\mathrm{CD} 25^{+} \mathrm{FoxP} 3^{+} \mathrm{CD} 4^{+} \mathrm{T}$ cells in tissues of unvaccinated and vaccinated macaques compared to SIV-naïve macaques is shown. Significant differences are indicated by the P values obtained after comparison of the SIV-naive and unvaccinated animals, the SIV-naive and vaccinated animals, and the unvaccinated and vaccinated animals. 


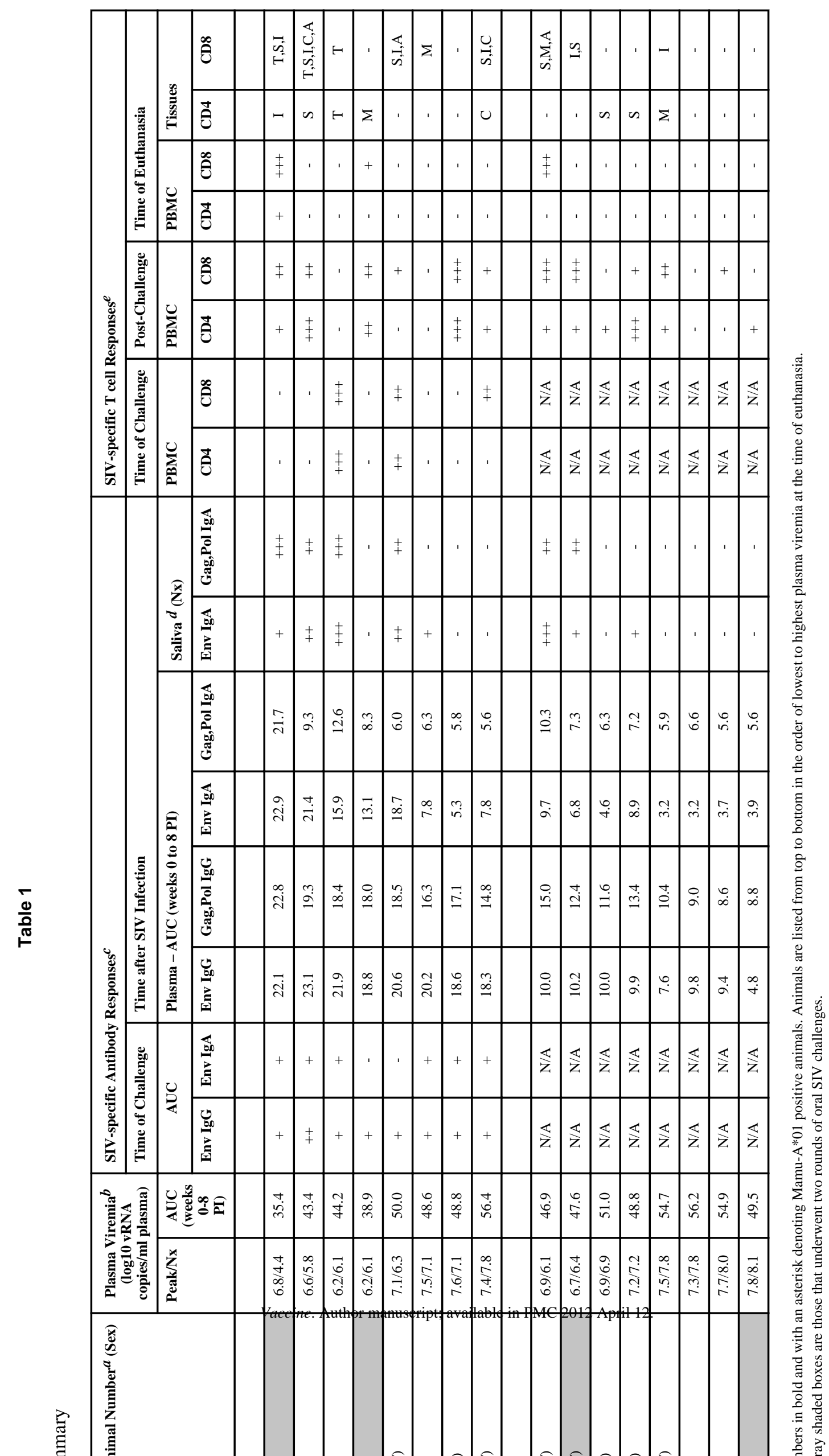

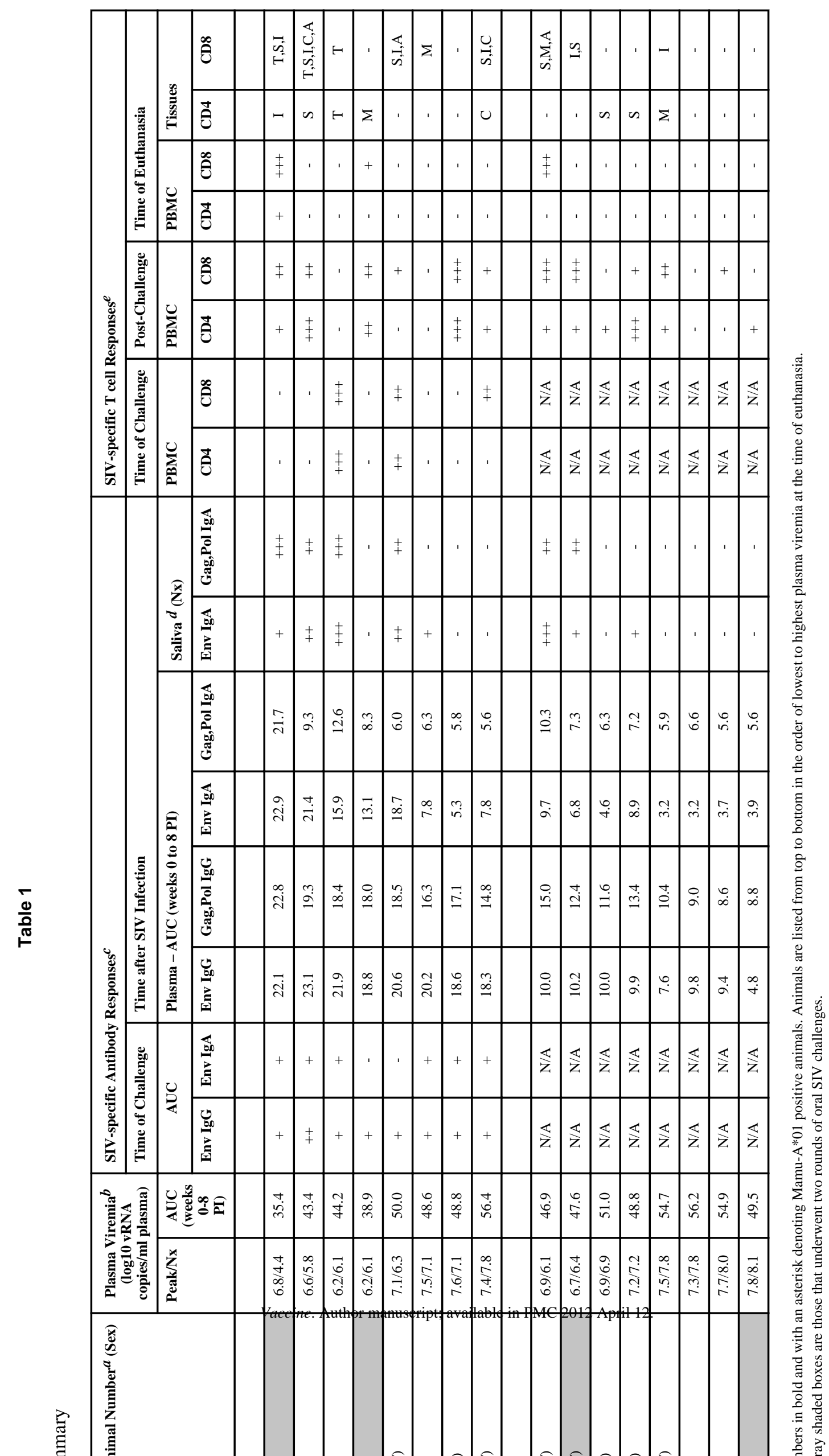




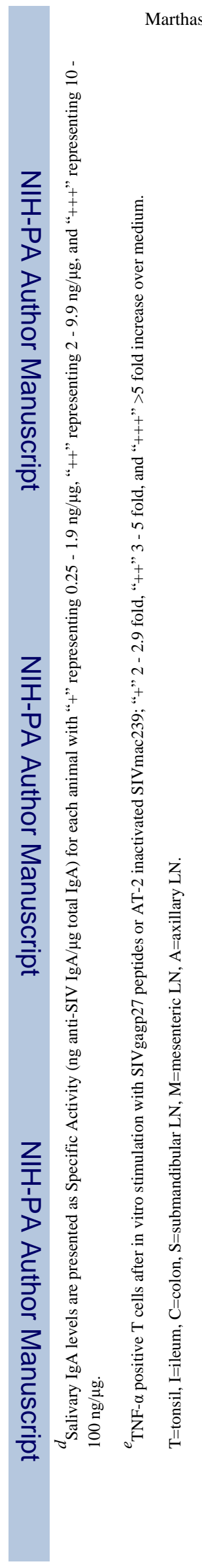

Page 24

Vaccine. Author manuscript; available in PMC 2012 April 12. 
Table 2

Virus Stock

\begin{tabular}{|l|l|l|l|l|}
\hline SIV Challenge Stock & Parent SIV Isolate & Vaccine & Challenge Regimen & References \\
\hline SIVmac251 8/95 & SIVmac251 from NENPRC & $\begin{array}{l}\text { Passive (sq) SIV hyperimmune } \\
\text { sera }\end{array}$ & 2 high doses & {$[40]$} \\
\hline SIVmac251 5/98 & 1998 SIVmac251 seed stock & $\begin{array}{l}\text { *** } \\
\text { 1) MVA-SIV; live attenuated } \\
\text { 2) MVA-SIV, ALVAC-SIV }\end{array}$ & $\begin{array}{l}\text { 1) 2 high doses } 15 \text { doses (5 days, 3x/day) } \\
\text { 2) }\end{array}$ & $\begin{array}{l}{[41]} \\
{[12]}\end{array}$ \\
\hline SIVmac251 2/02 & 1998 SIVmac251 seed stock & $\begin{array}{l}\text { MVA-SIV, ALVAC-SIV } \\
\text { (juvenile macaques that were } \\
\text { vaccinated as infants) }\end{array}$ & $\begin{array}{l}\text { weekly dosing until plasma } \\
\text { SIV positive }\end{array}$ & {$[12]$} \\
\hline SIVmac251 6/04 & 1998 SIVmac251 seed stock** & VSV-SIV and MVA-SIV & $\begin{array}{l}\text { one or two regimen of 15 } \\
\text { doses (5 days, 3x/day) }\end{array}$ & current study \\
\hline
\end{tabular}

SIVmac251 was a gift from Dr. Desrosiers (NENPRC); the virus was briefly expanded on PBMC in 1995.

* SIVmac251-8/95 was serially passaged in rhesus macaques in 1998 [42]; SIV isolated from plasma of rhesus macaque 26108 [42] was expanded briefly on CEMx174 cells and cryopreserved to produce the 1998 seed stock which was then used to grow up future SIV challenge stocks in rhesus PBMC [41]. To maximize viral diversity, each viral stock is the result of pooling supernatant from separate SIVmac251-infected cultures of PBMC from 6 to 8 rhesus macaques. 